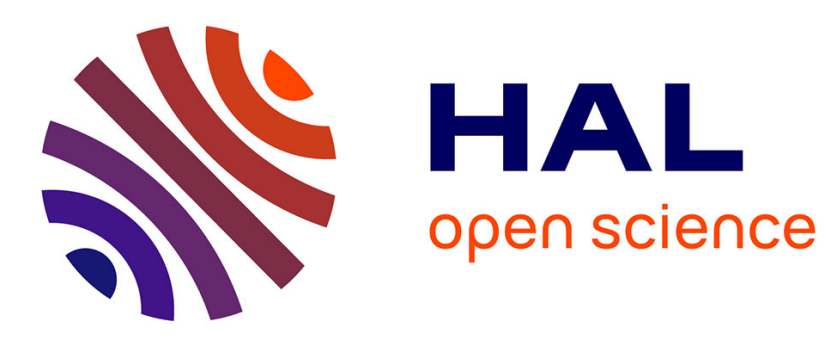

\title{
An empire divided: french natural philosophy (1670-1690)
}

Sophie Roux

\section{To cite this version:}

Sophie Roux. An empire divided: french natural philosophy (1670-1690). Garber, Dan; Roux, Sophie. The Mechanization of Natural Philosophy, Springer, pp.55-98, 2012, 9789400743441, 978-9400743441. 10.1007/978-94-007-4345-8_3. halshs-00807062

\section{HAL Id: halshs-00807062 https://shs.hal.science/halshs-00807062}

Submitted on 7 Apr 2013

HAL is a multi-disciplinary open access archive for the deposit and dissemination of scientific research documents, whether they are published or not. The documents may come from teaching and research institutions in France or abroad, or from public or private research centers.
L'archive ouverte pluridisciplinaire HAL, est destinée au dépôt et à la diffusion de documents scientifiques de niveau recherche, publiés ou non, émanant des établissements d'enseignement et de recherche français ou étrangers, des laboratoires publics ou privés. 


\section{AN EMPIRE DIVIDED: \\ FRENCH NATURAL PHILOSOPHY (1670-1690)}

\section{INTRODUCTION}

For some thirty years, historians of science and philosophy working on the seventeenth century have endeavored to blur the edges of an opposition that had until then been generally accepted, namely, between the "new philosophy" on [the] one hand and an "old philosophy" on the other. In a nutshell, this generally received opposition was based on the idea that there had been a Scientific Revolution in the seventeenth century that consisted not only of the appearance of new sciences or of the discovery of new results in old sciences, but also of a change in the very principles of natural philosophy. From an ontological viewpoint in particular, the "new philosophers" had the right idea of substituting the clear principles of matter and motion for the old obscure entities that were the various occult qualities, substantial forms and virtues of all sorts. And thanks to these new ontological principles, which earned the new philosophers who defended them the title of "mechanical philosophers," it became possible to begin truly to explain natural phenomena and the triumphal road to modern physics was opened.

There were several ways to question the opposition of old and new, as well as the idea that, because of the intrinsic weakness of their principles, ancient philosophers were doomed to disappear when modern philosophers arose. ${ }^{2}$ These ways have more or less all been used in

\footnotetext{
${ }^{1}$ Before my arrival in Grenoble, I presented this paper in Paris, Oxford and Aix-en-Provence; I wish to thank the organizers of the corresponding seminars and conferences for giving me the opportunity to make my point more precisely, and the audiences for having obliged me to do so. Unless otherwise indicated, translations are mine.

2 In the words of Brockliss, "Descartes, Gassendi, and the Reception of the Mechanical Philosophy," p. 465:

"Twenty years ago, when historians accepted the propaganda of mechanist philosophers, this [the question "why in the course of the half century or so after 1660 some form of the mechanical philosophy replaced scholastic Aristotelianism as the predominant physical philosophy all over western and central Europe"] was an easy question to answer: seventeenth-century Aristotelians were obscurantists, philosophical dinosaurs condemned to extinction in the new world of the Scientific Revolution. Today, ... it is a question that seems to become more and more difficult to solve." Brockliss wrote this in 1995.
} 
the historiography of these last thirty years. It has been noted that the clarity of the mechanical explanations was at times insufficient and at times illusory, in particular because they turned out to be tautological; more radically even, it was argued that clarity and obscurity are relative epistemic criteria, depending on accepted etiologies and ontologies. ${ }^{3}$ Learned studies have shown that the great authors owed more to the Scholastics than they had been willing to admit, and for the lesser authors, that they had at times taken such complex positions that the division between the old and the new became as such practically impossible. ${ }^{4}$ Other studies pointed out the autonomy of scientific practices: it is now clear that the step was ultimately rarely made from new scientific practices to the formulation of alternative principles of natural philosophy, even in this philosophical age. ${ }^{5}$ In particular, it was entirely possible to participate in the new scientific practices while remaining either silent on the question of the principles or an Aristotelian of the strictest obedience, and conversely, to be an innovator in principles, while lacking initiative or coherence when dealing with science. Lastly, while mechanics and astronomy were placed at the heart of the Scientific Revolution, disciplines or ways of thinking once considered as peripheral, such as the hermeticism and naturalism of the Renaissance, alchemy or chemistry, and medicine, were put back on the table. ${ }^{6}$ In short, because of all these works, but also, undoubtedly, because of a general historiographic trend to privilege local and singular case studies over sweeping panoramas, the categories of old and new philosophy are today under the constant

\footnotetext{
${ }^{3}$ See for example, on the first point, Chalmers, "The Lack of Excellency of Boyle's Mechanical Philosophy"; Gabbey, "Mechanical Philosophies and their Explanations"; on the second point, Hutchison, "Dormitive Virtues, Scholastic Qualities and the New Philosophies."

${ }^{4}$ In this respect, Des Chene, Physiologia, and Leijenhorst, The Mechanisation of Aristotelianism, are exemplary studies. About the complexity of minores, among a flourishing literature, see for example Henry, "Occult Qualities and Experimental Philosophy”; id., "Robert Hooke, the Incongruous Mechanist”; Lüthy, “Thoughts and Circumstances of Sébastien Basson”; id., “An Aristotelian Watchdog as Avant-Garde Physicist. Julius Caesar Scaliger"; id., "David Gorlaeus’ Atomism."

${ }^{5}$ On the autonomy of scientific practices, see for example Bennett, "The Mechanics' Philosophy and the Mechanical Philosophy." On the specificity of the seventeenth century with regard to the "vexing problem of the nature of natural philosophy," see Lüthy, "What to Do With Seventeenth-Century Natural Philosophy?," pp. 165-167, 174-177.

${ }^{6}$ See for example Yates, Giordano Bruno and the Hermetic Tradition; Rhigini Bonelli and Shea (eds.), Reason, Experiment and Mysticism in the Scientific Revolution; Westman and McGuire (eds.), Hermeticism and the Scientific Revolution; Newman, Gehennical Fire: The Lives of George Starkey; id., Atoms and Alchemy; Principe, The Aspiring Adept: Robert Boyle and its Alchemical Quest; Clericuzio, Elements, Principles and Corpuscles; Maclean, Logic, Signs and Nature in the Renaissance.
} 
suspicion of being both conceptually ill defined and without any real historical pertinence. It is particularly feared that they merely represent a bad partition of seventeenth-century natural philosophies, ill suited for drawing out their inexhaustible richness, and poorly distinguished one from the other.

It is not bad for us intellectual historians to lose a bit of our innocence - in less metaphorical terms, to notice that the categories of ancient and modern philosophers are not natural givens, and to ask to what we commit ourselves to when we use them. And yet, fleeing to local and singular case studies is no more satisfying than indulging in sweeping panoramas: panoramas may erase the differences, but case studies may be so particular that it is not even possible to see in which respect they differ from other particular case studies. More specifically, at least two reasons could allow us to restrain ourselves from wholly banning the opposition between these two categories, or, what comes down to almost the same thing, from using them with the intellectual tweezers of quotation marks. As we will see, the first reason is just a hackneyed version of the idea that there had been a Scientific Revolution in the seventeenth century; the second reason, however, will lead us to the heart of this paper.

The first reason may come from the spontaneous feeling that there is a family resemblance between Descartes, Hobbes or Gassendi, and that this resemblance is stronger than the resemblance between any two of these authors and, for example, Thomas Aquinas, Ockham, Bradwardine or Oresme. To illustrate this feeling by a comparison taken from a common experience, when you look at pictures of early twentieth-century French bourgeois, you do not differentiate them according to the kind of professional life they led; what strikes you is rather their common historical look: before being doctors or traders, the ancestors of our doctors and of our traders, you see them as men of their time, a time separated from ours by some profound changes. But does this comparison hold, and can we find in such a feeling some good reasons to maintain the opposition of the old and the new? I doubt it.

Taking previous studies as a starting point, in particular those of Edward Grant and Charles B. Schmitt, one can contrast an essentialist conception of the Aristotelian tradition, according to which Aristotelianism has a hard doctrinal core that cannot be touched, with a Wittgensteinian conception, according to which the fundamental plurality and diversity of Aristotelians should be accepted. According to the Wittgensteinian conception, Aristotelians 
form a family loosely linked by resemblances. ${ }^{7}$ Such a move could indeed be taken in most areas in intellectual history. When we seek to constitute historically pertinent categories, the problem is never the establishment of the essential identity of two works, or even of two propositions, a task that would be impossible. Rather, it is to look for resemblances between certain works, and then to propose a weighing of these similarities so as to give substance to the conviction that there is indeed something like a family resemblance between one work and another. Prima facie, Wittgenstein's metaphor of family resemblance has thus the advantage of allowing a looser use of categories like "Aristotelian," "mechanical philosopher," "seventeenth-century philosopher," and the like. But the problem lies in this very looseness: since we have no proper means of knowing what kind of resemblances should be taken into account and how the various similarities should be weighed, it is highly probable that, when we speak of "the modern philosophers (or scientists)" with no further specification, we are actually relying on the tacit assumption that a Scientific Revolution happened in the seventeenth century, and on some other tacit assumptions about the nature of this Scientific Revolution.

Thus, the feeling that there is a stronger family resemblance between Descartes, Hobbes, and Gassendi than between any two of these authors and, for example, Thomas Aquinas, Ockham, Bradwardine or Oresme, as long as it is not more precisely substantiated, might turn out to be the reheated cabbage of the old Scientific Revolution. That is why I prefer to flee to a safer ground and to insist on another reason for not banning the opposition between the old philosophers and the new philosophy. This second reason is that philosophers of the seventeenth century themselves considered their intellectual enterprise in terms of a battle between two camps, the ancient philosophers and the modern philosophers. It is possible that in so doing, the philosophers, both ancient and modern, were under an illusion as to their own historical situation, that they were dominated by their polemic spirit rather than governed by a concern for precision and intellectual rigor. Nevertheless, this stance was significant to them, and, as such, it had some real effects that can be the object of a second-order historical analysis. In other words, and to use once again a comparison, even if the categories of old and new are not legal tender, they are nonetheless a currency that, good or bad, actually circulated. Hence, it might be worth studying how a work of historical

\footnotetext{
7 Thijssen, "Some Reflections on Continuity and Transformation of Aristotelianism in Medieval (and Renaissance) Natural Philosophy." This paper actually finds in Lovejoy and Lakatos the first glimmers of a third way, that I shall not discuss here.
} 
categorization and demarcation between sides, of ordering and partitioning the empire of natural philosophers, was carried out in the seventeenth century. This is precisely what is at stake in this paper.

\section{A DEBATE ON NATURAL PHILOSOPHY}

Yet, such an enterprise immediately calls for a series of remarks that will help me to focus on a specific debate. To begin with the most obvious point: the result of the demarcation process between the old and the new philosophers differed according to time and place. It is not only that those that are called "new" are by definition always changing; it is also that the very format of the categorization changed. Indeed, until the middle of the seventeenth century, the lists of innovators are very long, and they include the authors who had attempted a reform of Aristotelianism from the end of seventeenth century on, mostly, but not only, in Italy; but after 1660, only a few great names remain, including, at the forefront, Descartes. Let us give a few references to substantiate this assertion.

In an Apologie written in 1625 to defend great men charged with magic, Gabriel Naudé, a physician and the librarian of the Président de Mesmes, mentions a "swarm of innovators that grows from one day to the next, under the guidance of Telesius [Telesio], Patrice [Patrizi], Campanella, Verulamio [Bacon], Jordan Brun [Giordano Bruno] and Basson, who have no other plan than to elbow aside this philosophy and ruin this great edifice that Aristotle and more than twelve thousand others who have interpreted him worked to build over so many years." In his Advis pour dresser une bibliothèque, written two years later, the swarm has indeed swelled since he adds to the previous novatores "Gilbert, Gassendi, Gomesius [Gómez Pereira], Charpentier [Carpenter], Gorlaeus," who, according to him, intend to inspire in all minds "a thousand [milliace] openings and new conceptions." $\mathrm{In}$ his Quaestiones ad Genesim (1623), Mersenne draws up several lists of novatores:

\footnotetext{
${ }^{8}$ Naudé, Apologie pour tous les grands hommes qui ont esté accusez de magie, chap. 13, p. 240, et, id., Advis pour dresser une bibliothèque, chap. 7, p. 133, quoted by Pintard, Le libertinage érudit dans la première moitié $d u X V I I^{e}$ siècle, pp. 451 f. In secondary literature, Antonio Gómez Pereira (1500?-1560?) is generally known because of his Antoniana margarita, which is supposed to have anticipated the Cartesian theory of animal machines; see also Navarro's paper in this volume. Here, however, Naudé was more likely thinking of Pereira's Nova veraque medicina experimentis et evidentibus rationibus comprobata. Nathanael Carpenter (1589-1638) published under the pseudonym of N. C. Cosmopolitanus the anti-Aristotelian treatise Philosophia libera triplici exercitationum decade proposita. The other names that Naudé mentions are familiar enough to us today.
} 
Campanella, Bruno, Telesio, Kepler, Galileo and Gilbert are mentioned in the Preface and, in the body of the book, Bacon, Fludd, Hill, Basso are to be met. ${ }^{9}$ A similar list is presented in L'impiété des déistes (1624), where Mersenne outlines his plan to write an Encyclopedia to refute all kinds of lies, and more particularly those of "Gorlee [Gorlaeus], Charpentier [Carpenter], Basso [Basson], Hill, Campanella, Brun [Bruno], Vanin [Vanini] and several others." 10 As for La vérité des sciences (1625), it places Patrizi among "Basson, Gorlaeus, Bodin, Carpentier [Carpenter], Hill, Olive" and other chicks who set their hearts on flying before their wings have grown, whereas Aristotle is compared to an eagle. ${ }^{11}$ In the Preface of his Cribrum philosophorum qui Aristotelem superiore et hac aetate oppugnarunt, composed in 1628, published in 1646, Jean-Cécile Frey, teacher of philosophy at various colleges of the University of Paris, explains that his intention is to refute all those who challenged Aristotelian doctrines, Campanella, Patrizi, Bacon, Telesio, Chassinus, Peter Ramus and recently the "Vile Villon."12 In 1630, Descartes explains that he owes nothing to his first mentor Beeckman nor to any philosopher, whether old or new; novatores are for him at this point Telesio, Campanella, Bruno, Basson and Vanini. ${ }^{13}$

We could think that nothing had changed over the next forty years when we read a letter from Leibniz to his former teacher Thomasius, in which he's already defending a reformist program relying on a reconciliation of the ancients and the moderns. ${ }^{14}$ Indeed,

\footnotetext{
${ }^{9}$ Mersenne, Quaestiones in Genesim, resp. Praefatio, n.p., and Paralipolema et observationes, col. 1838. Nicolas Hill (1570?-1610?) published a Philosophia epicuraea, democritiana, theophrastica. Daniel Garber mentioned this text to me; in his essay in this volume, he calls attention to largely the same lists of novatores, though he makes somewhat different use of them, contrasting the earlier novatores with the later mechanical philosophers.
}

${ }^{10}$ Mersenne, L’impiété des déistes, athées et libertins de ce temps, I, pp. $238 \mathrm{f}$.

${ }^{11}$ Mersenne, La vérité des sciences contre les sceptiques ou pyrrhoniens, I, 9, p. 109. I was not able to identify Olive.

12 This passage is quoted and commented by Ariew and Garber, in their introduction to Frey, Cribrum philosophorum. Geoffroy Chassins [15??-16??] is the author of a De natura sive de mundo. Antoine de Villon advanced in 1624, together with Étienne de Clave and Jean Bitaud, twenty-four anti-Aristotelian theses, that were condemned by the Parlement of Paris, at the request of the Faculty of Theology; the main documents of this affair are published in Kahn, "La condamnation des thèses d'Antoine de Villon et Étienne de Clave."

13 Descartes to Beeckman, 17 October 1630, in Descartes, Euvres, vol. I, p. 158.

${ }^{14}$ Leibniz to Thomasius, 30 April 1669, Leibniz-Thomasius, Correspondance, p. 97. According to Bodéüs, ibid., p. 119, in a dissertation from 1665, Thomasius identified as innovators Cardano, Campanella, Fludd, Gilbert, Comenius, Hobbes and Digby. 
Leibniz makes a long list of moderni, whom, he wrote, Thomasius should censure as he censured the now-unknown Michel Baghemihn, a municipal magistrate in Stettin. With all the erudition required when addressing one's former teacher, Leibniz gathers at this point at least three generations of innovators: he begins quite traditionally with the Aristotelian naturalists of sixteenth-century southern Europe (Patrizi, Telesio, Campanella, Bodin, Nizolio, Frascator, Cardano), then he goes on with philosophers of the early seventeenth century to whom we would today attribute different orders of greatness (Galileo, Bacon, Gassendi, Hobbes, Descartes, Basson, Digby, Sennert), and finally he ends up with Protestant partisans of atoms from Thomasius' own generation, whom almost nobody remembers today (Sperling, Derodon, Deusing). ${ }^{15}$ And yet I think that Leibniz was here the exception that confirms the rule, the general tendency being at the time to simplify the story and to cut down on the catalogue of innovators.

For example, in the Advertissement of his voluminous Physica, published in 16691671, Honoré Fabri criticizes the recentiores who, confounding physics and geometry with forging hypotheses at leisure, are as ridiculous as Democritus, who thought it necessary to tear out his eyes in order to better understand corporeal things. The allusion is crystal clear: he holds a grudge against Cartesians. ${ }^{16}$ It is perhaps Daniel who best expressed the tendency I

\footnotetext{
15 Johann Sperling (1603-1658), professor of medicine at Wittenberg, was so prolific an author that it is not easy to pin down the book to which Leibniz refers; note however that he published the Antiparasceve. Pro traduce, in which, following his mentor Daniel Sennert, he rejected the Aristotelian theory on the origin of forms. Anton Deusing (1612-1666), professor of medicine in Groeningen, is the author of the Disquisitio physico-mathematica gemina de vacuo et de attractione. As for David Derodon (1600?-1664), Leibniz may here be thinking either of his Disputatio de libertate et atomis, or of his more popular Philosophia contracta. This triplet confirms the studies arguing that there was an affinity between Protestantism and physical atomism, see for example Heyd, Between Orthodoxy and Enlightenment: Jean-Robert Chouet and the Introduction of Cartesian Science in the Academy of Geneva; Leijenhorst and Lüthy, "The Erosion of Aristotelianism"; Brockliss, "Pierre Gautruche et l'enseignement de la philosophie de la nature," pp. $207 \mathrm{f}$.

16 “[U]nde est, quod novas \& inanes quorundam recentiorum physicas hypotheses reiicas, qui ut novam physicam facerent, novam sibi naturam, novumque mundum fabricarunt; nec tam apud illos invenias, quid re ipsa sit, quàm quid ab iis fictum sit; novum sibi mundum finxerunt, nova, seu potiùs nulla elementa; non coelestes globos, at subtilis materiae turbines, seu vortices; Democritico certè suo haud absimiles, esse voluerunt, qui ut res corporeas, sensibiles, \& visibiles meliùs intelligeret, oculos, ut aiunt, eruendos sibi esse putavit” (Fabri, Physica, Auctor lectori, § 3, n.p.). In Fabri’s works, Descartes is the Democritean leader, democritici being those who explain everything through three principles, moles, figura, motus, see for example ibid., § 33; id., Epistolae tres de sua hypothesi philosophica, I $§ 23, \S 27, \S 30$, resp. p. 52, p. 58, p. 62; id.,
} Euvres de Fabri, vol. II, ff. 75-77; vol. IV, f. 102r, ff. 207v-209r. 
am trying to capture. In 1691, he notes that, except in schools, Thomists, Scotists and Nominalists are not distinguished anymore: "We put them all in the same category, and in the same party, which we call ancient philosophy, to which we contrast the philosophy of Descartes, or the new philosophy. You [Descartes] have even had the good fortune to erase, in a way, everything that appeared from the new philosophers at the same time as you." Just as it was customary in sixteenth-century Spain to call all heretics Lutherans, whatever their particular sect, it is now usual, Daniel adds, to call "Cartesians" all those who try to elaborate more sophisticated opinions in physics. Even Gassendi happens to be put among Descartes' disciples, although he is older than Descartes. ${ }^{17}$ In sum, at this moment, the innovators were no longer the sixteenth-century swarm of prolific Renaissance Aristotelians, but the disciplined and undifferentiated cohort of followers of Descartes, among whom Gassendists are to be found.

Lists of innovators of the years 1670-1690 confirm Daniel's diagnosis, whether they were drawn up by old or new philosophers. On the side of the old philosophers, Jean-Baptiste de La Grange (1678) states explicitly in the title of his book that his target is "the new philosophers, Descartes, Rohault, Gassendi, Father Maignan"; 18 in the body of his book, he names in addition Regius and criticizes Malebranche's doctrine of vision in God. ${ }^{19}$ When Louis Le Valois, in his book published in 1680 under the pseudonym of Louis de la Ville, wants to establish that, according to every Cartesian, the essence of matter is extension (Maignan and Cordemoy being the exceptions that confirm the rule since they do not back such a thesis), he successively examines those who are, according to him, Cartesian authors: Clerselier, de la Forge, Rohault, the author of Discours sur les Entretiens de M. Rohault, the author of Recherche de la vérité (Malebranche), Cally, Bernier, Gadroys, Antoine Le Grand,

\footnotetext{
${ }^{17}$ Daniel, Voyage du monde de Descartes, pp. $184 \mathrm{f}$. Daniel is not completely consistent when he mentions, p. 113, "les chefs des nouvelles Sectes de Philosophie, entre lesquels nous réconnûmes aisément M. Descartes, M. Gassendi, le P. Maignan, \& plusieurs autres.”

${ }^{18}$ Emmanuel Maignan (1601-1676) was a Minim teaching philosophy in Toulouse; his Cursus philosophicus, is famous for rejecting substantial forms and being committed to atoms and void, but it also contains a mechanical explanation of transubstantiation, reproduced in Maignan's Philosophia sacra, and commented on by Rohault, Entretiens sur la philosophie, pp. 120-122.

${ }^{19}$ La Grange, Les principes contre les nouveaux philosophes, Preface, §§ 33-39, pp. 30-38; chap. 4, §§ 5-13, pp. 77-87.
} 
Ambroise Victor, the author of Critique de la Critique de la Recherche de la vérité (Robert Desgabets), and the author of De l'éducation des dames (François Poullain de la Barre). ${ }^{20}$ Ancients and moderns disagreed on many things, but they at least did agree on who was what. The Requeste des maîtres es arts (1671) counts as innovators scientists from the previous generation (Blaise Pascal, Gilles Personne de Roberval) or from the Académie des sciences (Jean Picard, Adrien Auzout, Jean-Dominique Cassini, Jean Pecquet), but in the final Arrêt "Cartists and Gassendists" are mentioned, the longest list including "Gassendy [sic], Descartes, Rohault, Denis, Cordemois [sic], Clercelier [sic], Delaunay [sic] and their followers" and the incriminated libelles being Rohault's Physics, Port-Royal Logic, and Gassendi's Exercitationes. ${ }^{21}$ When Malebranche responds to Le Valois, who decided at some

${ }^{20}$ Le Valois, Sentimens de M. Descartes touchant l'essence et les proprietez des corps, I, chap. 4, pp. 61-86. The Discours sur les Entretiens de M. Rohault mentioned here is probably the Discours sur les sujets traités dans les Entretiens de Mr. Rohault that replaced Rohault's Preface in the $3^{\text {rd }}$ edition of his Entretiens sur la philosophie (1673). The priest Pierre Cally (1630-1709) is, with Rohault and Malebranche, the author the most frequently quoted by Le Valois: this does not result from the intrinsic quality of his Institutio philosophiae, or of his Universae philosophiae institutio, but rather from his being Le Valois' local rival. Like Le Valois, Cally was at the time a professor of philosophy in Caen, albeit at the secular college du Bois, not at the Jesuit college: he was introduced to Cartesianism by Pierre-Daniel Huet in the sixties, defended physical atomism, but objected to animal-machines and to plant-machines; according to Bayle, Nouvelles de la République des Lettres, January 1687, pp. 96 f., he was dismissed from Caen with two of his fellows for Jansenism and Cartesianism. Claude Gadroys (1642?-1678), secretary of the quartermaster of the Armée d'Allemagne and in charge of the military hospital in Metz earned his reputation as a Cartesian because of his Discours sur les influences des astres selon les principes de M. Descartes. The Franciscan Antoine Le Grand (160?-168?) first taught philosophy in Douai, then in London, where he published in 1675 his Institutio philosophiae, secundum principia Renati Descartes; Le Valois may also have heard of his Apologia pro Renato Descartes, contra Samuelem Parkerum. The Oratorian Ambroise Victor (1621-1695) was professor of theology and philosophy in Saumur; he published five volumes of Philosophia cartesiana in Paris in 1667; a sixth volume defending the thesis of animal-machines was published in Saumur in 1671. La critique de la critique de la Recherche de la vérité is the answer by Dom Robert Desgabets (1610-1678) to Simon Foucher's Critique de la Recherche de la vérité. The author of De l'éducation des dames pour la conduite de l'esprit dans les sciences et dans les mours, Paris, J. du Puis, 1674, is François Poullain de La Barre (1647-1725).

21 Boileau et al., Requeste des maitres es arts, pp. $236 \mathrm{f}$. In the many editions of the Requeste that were published in the late seventeenth century and early eighteenth century, Malebranchists and Pourchotists were added to Cartists and Gassendists. Gilles de Launay gave popular Gassendist conferences in Paris as early as the mid-1650s; among other work, he published Les essais physiques, Dissertation de la philosophie, and Les essais métaphysiques du sieur de Launay. Jean-Baptiste Denis (1640-1704) was ordinary consulting physician to 
point to include Bernier among Cartesians, notwithstanding the fact that he professes to be Gassendist, he opposes Cartesians and Gassendists to the new Aristotelians and takes over his opponent's classification, mentioning the author of Recherche, Clerselier, Cally, Bernier. ${ }^{22}$ Thanks to a well-known parable that begins with an analogy between nature and an opera, Fontenelle lets his Marquise of the Entretiens sur la pluralité des mondes (1685) note how philosophy became mechanical. When she inquires about the actors of this transformation, he unswervingly answers: "Descartes and a few other Moderns."23

Many examples of similar lists could be given. In all of them, Renaissance Aristotelians have disappeared, Cartesians and Gassendists are united against unnamed philosophers of the School, and, sometimes but not always, Gassendists appear as a subset of the Cartesian set. This partition of the empire of natural philosophy presents in my eyes two characteristics that constitute two good reasons to explore it more thoroughly.

First, this partition succeeded in becoming stable beyond the particular moment of its inception. Even today we continue to use it when we refer to Descartes as the archetype of the early modern natural philosopher, the absolute reference in novelty, the benchmark by which the works of other natural philosophers of the seventeenth century fall either on the side of the old or the new (or are even forgotten). This alone would be sufficient to focus on this division, but a second characteristic gives further support.

To state once again the obvious: if a demarcation between two camps is to be studied, it is important not unduly to privilege one of them. In the case at hand, this is not always easy, not only because the court of history has judged in favor of the moderns, but also because the ancients, who, by definition, lived before the moderns, did not have the opportunity to refute them: you can indeed contrast the views of Thomas Aquinas and Descartes on a given topic, but you find no refutation of Descartes by Thomas Aquinas to comment on. In fact, most of the works which try to re-evaluate scholastic works written in the late sixteenth or early seventeenth centuries (rarely those of the Aristotelians of the late seventeenth century) presuppose that since the Scholastics are per definitionem conservative,

\footnotetext{
Louis XIV; he is famous for having performed the transfusion of blood in dogs and in men in 1667-1668. Denis is the author of Recueil des mémoires et conférences qui ont esté presentées à Monseigneur le Dauphin.

${ }^{22}$ Le Valois, Sentimens de M. Descartes touchant l'essence et les proprietez des corps, § 47, p. 83: “M. Bernier, quoyqu'il fasse profession d'estre tout Gassendiste, \& nullement Cartesien”; Malebranche, Euvres complètes, vol. XVII-1, pp. 486, 488.

23 Fontenelle, Entretiens sur la pluralité des mondes, in CEuvres complètes, vol. II, p. 21.
} 
they did not evolve. ${ }^{24}$ And yet, these Aristotelians did not vanish into thin air when Gassendi, Descartes, Mersenne, or Hobbes appeared, and they most likely had successors capable of reacting to the new philosophers, whether to argue against them, to adopt some of their views, or to formulate more or less promising compromises. In other words, if we wish to apply an elementary principle of symmetry to philosophers, we must find moments when they actually exchanged arguments with each other. From this point of view as well, the partition of natural philosophy into the old and the new in France between 1670 and 1690 is interesting to study.

The circumstances in which this confrontation took place are well known. In the middle of the 1660s, Claude Clerselier, who was at the time in charge of editing Descartes' correspondence, and, to put it bluntly, was the general of the Cartesian army, launched a campaign among theologians to win support for the explanations of the Eucharist that Descartes had proposed in response to objections from Arnauld and, later on, in two letters to Mesland. Clerselier was soon assisted in his efforts by Dom Robert Desgabets, who imagined explanations of this mystery of his own devising. 25 Through a series of events, the details of which do not need to retain our attention here, their propaganda actually led to condemnations of Cartesian philosophy pronounced by the King, the University and the teaching orders. Descartes' works had already been put on the Index of Prohibited Books donec corrigantur in Rome in $1663 .{ }^{26}$ In 1671, the King of France sent to the University of Paris, via the Archbishop, the order to teach "no other doctrine than the one brought forth by the rules and statutes of the University," and this to "prevent the course of an opinion that could bring some confusion in our mysteries"27 (1671). Following a two-year conflict between some Oratorians of Angers, including Bernard Lamy and the rector of the University of the same city, an Arrêt of the Conseil d'État explicitly forbade them to teach Cartesian

\footnotetext{
${ }^{24}$ Here also, there are some exceptions that confirm the rule, see for example the confrontation between Descartes and Schoock, as now presented in Theo Verbeek, La querelle d'Utrecht; Blackwell and Kusukawa, Philosophy in the Sixteenth and Seventeenth Centuries.

25 Descartes' and Desgabets' explanations are studied in Armogathe, Theologia cartesiana; see as well Ariew, Descartes and the Last Scholastics, chap. 7, pp. 140-154.

26 Documents concerning this condemnation are published in Armogathe and Carraud, "La première condamnation des Euvres de Descartes, d'après des documents inédits des Archives du Saint-Office." ${ }^{27}$ I follow Ariew's translation, "Damned if You Do," pp. $257 \mathrm{f}$. The order of the King referred to the condemnation of 1624 mentioned supra, note 12.
} 
philosophy in any way or manner whatsoever, ordered their works, including lecture notes and theses, to be examined by the rector, and reasserted the power of the Faculty of Theology over the Faculty of Philosophy (1675). In Caen, where Pierre Cally was teaching, the Faculty of Theology prohibited the teaching of Descartes' philosophy, on pain of being refused access to any academic grade (1677). The Chapter General of the Benedictines of St. Maur and of the Genofevins condemned Jansenism and Cartesianism in a single stroke (1675 and 1678 respectively). More importantly, to comply with the Jesuits, and after several local conflicts, the General Assembly of the Oratorians issued a decree spelling out what should be taught and what not (1678). The professors of the Parisian Faculty of Arts finally followed their colleagues of the Faculties of Theology and of Medicine in their ban on Cartesianism, and made a list of prohibited propositions (1691). The last noteworthy condemnation in the period that we consider is by the General Assembly of the Jesuits in 1706.28

Until 1691, the focus of these condemnations, when explicit, is not on the dangers of doubting, as it will be later on, but on the danger that Cartesian physics constitutes for the mysteries of the (Catholic) faith, namely the mystery of Eucharist as officially defined in 1551 by the Council of Trent. Namely, the Cartesian thesis by which the essence of the body is extension and its consequence that the sensible qualities we perceive in bodies, without really belonging to them, result from certain configurations and motions of the extended substance, are judged incompatible with two aspects of the Eucharist. First, according to this mystery, the whole body of Jesus Christ is genuinely, and not symbolically, present in every host; hence, if we admit that the essence of the body is extension and that all extension is local, the body of Jesus Christ has the same local extension as the host. This is however absurd: the extension of the host is too small to contain the body of Jesus Christ; at a given time, there are several hosts in different places of the world, but only one Jesus Christ. Second, according to the dogma of transubstantiation, the species of wine and bread are real accidents, not false appearances, and they are distinct from the corporeal substance, so that

\footnotetext{
28 The main facts and documents are to be found in Babin, Journal; Bayle, Recueil de quelques pièces curieuses; Duhamel, Philosophia universalis, vol. V, Appendix, pp. 1-45. For recent accounts, see Cousin, "De la persécution du cartésianisme en France,” in Fragments philosophiques, vol. III, pp. 297-332; Bouillier, Histoire de la philosophie cartésienne, vol. I, pp. 466-485; McClaughin, "Censorship and Defenders of the
} Cartesian Faith"; Ariew, "Quelques condamnations du cartésianisme”; id., "Damned If You Do"; id., "Bernier et les doctrines gassendistes et cartésiennes de l'espace" (a French version of the previous text); id., Descartes and the Last Scholastics, chap. 9 (another English version), pp. 172-187; Azouvi, Descartes et la France, pp. 19-28, 38-47. The motivations behind censorship are variously interpreted, but I shall not discuss this question here. 
they can subsist when the host is changed to Jesus Christ; but, in the Cartesian natural philosophy, all sensible qualities are appearances that necessarily result from certain configurations and motions of the corporeal substance. It is thus impossible in Cartesian physics to have sensible accidents that do not result from the corporeal substance, yet this is precisely what happens in transubstantiation.

To be sure, this kind of reasoning takes up many pages in the books that I consider here and the entirety of some other works that I will not be considering. ${ }^{29}$ Moreover, it can reasonably be argued that a general ongoing question was at stake: how should one solve a conflict between a truth of the faith (the mystery of Eucharist) and a truth of the reason (the Cartesian theses on matter), or, to put the matter in institutional terms, between theology and philosophy? According to the new philosophers, reason should not be used to judge the mysteries of the faith, and, reciprocally, faith should not be used to decide matters of reason: this amounts to giving reason a definite autonomy with respect to faith and to assert that one can, as a simple physicist, talk about things as they are in their natural state. ${ }^{30}$ According to the old philosophers, however, the relation is not reciprocal and precedence should be given to faith over reason: to be sure, reason should not be used to judge the mysteries of the faith, but faith has a right of inspection with respect to reason, simply because faith is the rule of truth. ${ }^{31}$ To sum up, according to the new philosophers, the competing claims of faith and

${ }^{29}$ See, among the ancients, La Grange, Les principes contre les nouveaux philosophes, Preface, $\S \S 2-4$, and chap. 6-8, resp. pp. 2-6 and pp. 99-135; Rochon, Lettre d'un philosophe à un cartésien de ses amis, §§ 2-9 et $\S \S$ 26-31, resp. pp. 4-17 and pp. 66-81; Vincent, Discussio peripatetica, II, sect. 5-6, pp. 55-60; Le Valois, Sentimens de M. Descartes touchant l'essence et les proprietez des corps, II and III, pp. 99-317; Charles-Joseph de Troyes, La philosophie de Monsieur Descartes contraire à la foi catholique; Huet, Censura philosophiae cartesianae, chap. 8, § 3, iv, pp. 173-185; and, among the moderns, Rohault, Entretiens sur la philosophie, pp. 119-137; Malebranche, De la recherche de la vérité, III, II, chap. 8, § 2, pp. 360-363, and the texts of the polemic with Le Valois, in Malebranche, Euvres, XVII-1, pp. 477-531; Arnauld, Examen du traité de l'essence des corps, pp. 29-63; Régis, Réponse à Huet, chap. 8, pp. 312-325.

30 Arnauld, Plusieurs raisons pour empêcher la censure ou la condamnation de la philosophie de Descartes, §§ 6-7, pp. 310-313; Rohault, Traité de physique, I, chap. 7, § 9, chap. 5, § 12-14 vol. I, pp. 35 and 41, passim; in Entretiens sur la philosophie, p. 111, Rohault refers to these declarations; Clerselier, Preface, in Rohault, Euvres posthumes; Malebranche, De la recherche de la vérité, III, II, chap. 8, § 2, p. 360.

${ }^{31}$ La Grange, Les principes contre les nouveaux philosophes, chap. 5, § 1, pp. 90 and 100; Le Valois, Sentimens de M. Descartes touchant l'essence et les proprietez des corps, II, chap. 3, art. 2 and art. 4, chap. 4, pp. 119-139, 147-149, 183-220; Babin, Journal, p. 42; Charles-Joseph de Troyes, La philosophie de Monsieur Descartes contraire à la foi catholique, Préface, p. iij; Huet, Censura philosophiae cartesianae, chap. 8, § 3, iv, pp. 173 f.; Daniel, Suite du voyage du monde de Descartes, p. 100. 
reason should be adjudicated by a separation of their respective domains of jurisdiction; the old philosophers argue, quite traditionally, for a submission of reason to faith. At this point, although he is not one of the authors we study in this paper, one cannot help thinking about a famous sentence by Bossuet, in his letter to one of Malebranche's disciples on 21 May 1687:

I see... a great combat being prepared against the Church under the name of Cartesian philosophy... under the pretext that one can only accept that which one understands clearly... there is introduced... a liberty to judge that means that, without regard to tradition, one boldly advances that which one thinks. ${ }^{32}$

In the following however, I would like to leave aside books (or parts of books) concerned exclusively with the mystery of Eucharist or with the relation of faith and reason, and to focus on the norms to be adopted in natural philosophy. Namely, it is noteworthy that the official censures and condemnations pronounced in the name of theology, as numerous and radical as they were, were not considered to be sufficient. They were assisted by numerous polemical works, the audience of which was not an assembly of narrow-minded regents and boisterous students but, rather, learned companies of courteous honnêtes gens, and the object of which was not (or not only) to reassert the rights of faith, but to defend a certain way of proceeding in physics. In the intellectual context of the time, it is somehow natural that official censorship was not felt to be a sufficient measure to eradicate Cartesianism and that, somewhat belatedly, old philosophers tried to get rid of their image as stubborn pedants, to become more popular among honnêtes gens and to respond to the rise of the new natural philosophy. ${ }^{33}$

In the $1660 \mathrm{~s}$, an intense Cartesian propaganda emerged, which involved personal patronage, even family networks, and ostentatious manifestations such as the reburial of

\footnotetext{
32 Bossuet to ***, 21 May 1687, in Bossuet, Correspondance, vol. III, pp. $372 \mathrm{f}$.

${ }^{33}$ La Grange, Les principes contre les nouveaux philosophes, Preface, $\S 44$, p. 40, declares this delay surprising: “Il est assez surprenant qu'il n'y a pas encore eu personne depuis vingt ans que la Philosophie de Descartes fait bruit, qui ait tâché de prouver la fausseté de ses opinions, \& la verité des principes de la philosophie commune"; Vincent, Discussio peripatetica, Dedicace, n.p., explains however that there is nothing surprising here, since twenty years earlier (he published the first volume of his Cursus philosophicus in 1658), nobody knew of Descartes: "Cum liberiori calamo coepi spargere in lucem publicam Cursum Philosophicum, nominare eum nec libuit ne oportuit; quia per id temporis latebat etiamnum ferme Anonymus, Et si jam alicuis nominis inter
} Arctoos, nullius erat in Gallia, vel ad summum tantilli." 
Descartes at Saint-Étienne-du-Mont in $1667 .{ }^{34}$ As far as publications are concerned, the Discours de la méthode, first published in the Netherlands, was reissued in Paris (1658, 1660), while numerous editions of Descartes' other works were released. His unedited works were posthumously published under the supervision of his followers: Claude Clerselier took care of the Letters in three volumes (1657-1667) and of Le monde (1664), Nicolas Poisson of mechanics and music (1668), Louis de La Forge of De l'homme (1664). Many books were issued to defend and illustrate the Cartesian cause: Du Roure's La physique expliquée suivant les sentiments des anciens et nouveaux philosophes; et principalement de Descartes (1653) being a special case, I am here rather alluding to works from Gérauld de Cordemoy, Nicolas Poisson, Louis de La Forge, Jacques Rohault, Antoine Arnauld, Nicolas Malebranche, PierreSylvain Régis. ${ }^{35}$ The ideas of Descartes were discussed in salons, conférences, or private academies; the aristocracy had Cartesian preceptors - the most eminent Cartesian aristocrats of the period are the duc de Luynes, prince Louis II de Condé, the marquis de Liancourt, the prince de Conti, the cardinal de Retz, the marquis de Pomponne and, of course, women like the comtesse de Grignan, the marquise de Sablé or the duchesse du Maine. ${ }^{36}$ In a word, the

\footnotetext{
${ }^{34}$ On familial networks involved in the defense of Cartesianism, see Azouvi, Descartes et la France, pp. 29-32; van Damme, Descartes, pp. $48 \mathrm{f}$.

35 On the diffusion of Cartesianism through books, see Bouillier, Histoire de la philosophie cartésienne, vol. I, pp. 430-437; Martin, Livre, pouvoirs et société, vol. II, pp. 874-883; Azouvi, Descartes et la France, pp. 32-35; van Damme, Descartes, pp. 29-37. Cartesians established a sort of editorial continuity between the master's work and their own, the first edition of Le monde being for example published together with a Discours de l'action des corps by Cordemoy and a Discours des fièvres by Rohault.
}

${ }^{36}$ On the social fashion of Cartesianism, see Bouillier, Histoire de la philosophie cartésienne, vol. I, pp. 437447; Cousin, "Le cardinal de Retz cartésien," in Fragments philosophiques, vol. III, pp. 140-296; Azouvi, Descartes et la France, pp. 32-35, 59-64; van Damme, Descartes, pp. 47-61. See however the disillusioned observations of Rochon, Lettre d'un philosophe à un cartésien de ses amis, § 91, p. 215: “Ils se flattent d'avoir dans leur party de grans Genies \& des personnes de la plus haute qualité. Mais ils se méprennent assurément, \& ne font pas assez de reflexion que ce sont deux choses que d'entendre Descartes, \& d'estre Cartesien. Ces grans esprits \& ces personnes illustres en naissance prennent plaisir à sçavoir ce qu'on dit.... Mais ils sont bien audessus de ces bassesses et de ces emportements"; and of Daniel, Voyage du monde de Descartes, p. 142:

“[C]ertains jeunes Abbez, Cavaliers, Avocats, Médecins,... se disent Cartésiens dans les compagnies, pour avoir un titre de bel esprit, qu'ils obtiennent quelquefois par la seule hardiesse de parler à tort \& à travers de matiére subtile, d'Automates, de phénomenes, sans sçavoir autre chose, que ces termes." Allusions to oral discussions of Cartesianism in salons and conférences are to be found in Rohault, Traité de physique, Preface, n.p.; Rohault, Entretiens sur la philosophie, pp. 110, 138, 150; Rochon, Lettre d'un philosophe à un cartésien de ses amis, §9, 
diffusion of Cartesianism was not confined to teaching institutions; from a social point of view, the philosopher was not only a professor, but also an author, and even a polished and worldly conversationalist. ${ }^{37}$ Consequently, if this diffusion was really to be stopped, the publication of lists of propositions was clearly not enough, because these were taught in relatively obscure and confined places such as colleges and universities. The honnêtes gens, learnèd but not specialized, good Christians but not furious theologians, were the ones to be convinced. ${ }^{38}$ That the audience of honnetes gens was the target not only of the moderns, but of some of the ancients as well, is clear by more than one allusion. ${ }^{39}$ This goes along with two characteristics of this debate.

First, concerning the format of their books, the philosophers I am concerned with often gave up heavy tomes for small in $12^{\circ}$ works that could fit in a hand or in a pocket. ${ }^{40}$ Most of the time, they deserted Latin for French. La Grange is the more explicit in this respect:

$\S 50, \S 75$, resp. pp. 19, 129, 172; Le Valois, Sentimens de M. Descartes touchant l'essence et les proprietez des corps, I, chap. 4, § 5, p. 61; Daniel, Suite du voyage du monde de Descartes, p. 48.

${ }^{37}$ For a long-term study of the various social figures of the philosopher, see Ribard, "Philosophe ou écrivain?"

38 Pascal famously said of the honnête homme that he could not be qualified as a mathematician, as a preacher, as being eloquent, but only as being an honnête homme; this is exactly what is at stake in the description of the public of Rohault's conferences given by Clerselier in the Preface he wrote for Rohault's Euvres posthumes, n.p.: “des personnes de toutes sortes de qualitez \& conditions, Prélats, Abbez, Courtisans, Docteurs, Médecins, Philosophes, Géometres, Régens, Escoliers, Provinciaux, Estrangers, Artisans, en un mot des personnes de tout âge, de tout sexe, \& de toute profession." Vincent, Discussio peripatetica, IV, sect. 526, p. 521, has a typical reaction of an Aristotelian professor in front of the new Cartesian public: "[E]vulgant ad omne hominum genus, pueros, adultos, viros, foeminas, doctrinam illam, quae in scholis ad paucos, solosque viros extenderetur." Vincent was teaching in Toulouse, where Régis had been sent in the mid-sixties by Rohault with the mission to propagate Cartesianism; Fontenelle, Éloge de M. Régis, in Euvres complètes, vol. VI, pp. 143 f., explains that Régis' success was such that the magistrates of the city awarded him a pension.

${ }^{39}$ Honnêtes gens are explicitly presented as the best judges in matter of philosophy in Rohault, Entretiens sur la philosophie, pp. 146, 154; Rochon, Lettre d'un philosophe à un cartésien de ses amis, §52, §76, §78, §82, resp. pp. 131, 176 f., 183 and 192 f.; Rapin, Réflexions sur la philosophie, Preface, pp. 329, 332. Ladies are mentioned and sometimes opposed to old professors by Rohault, Entretiens sur la philosophie, p. 152; Rochon, Lettre d'un philosophe à un cartésien de ses amis, $\S 78$ and $\S 81$, resp. pp. 183 and 188; Daniel, Voyage du monde de Descartes, pp. 140, 161; Huet, Nouveaux mémoires pour servir à l'histoire du cartésianisme, p. 49. 40 As noted by Brockliss, "Pierre Gautruche et l'enseignement de la philosophie de la nature," pp. $189 \mathrm{f}$., plenty of manuals were published after 1650, but, except for Gautruche's Philosophiae ac mathematicae totius institutio, not by Jesuits. 
I first composed the greater part of this work in Latin, with the idea I had that the Latin language would better suit the matter with which I was dealing than would the French language. I also believed that reading the work should be allowed only to the learned [gens d'estudes]. But, in addition to the fact that most books of our new philosophers are in French, and that it is about undeceiving those that may study their books and follow their feelings, I do not know how it has happened that the most knowledgeable people prefer French books to those in Latin; it seems that Latin is being neglected, because it is too old, and this language will share the same fate as ordinary philosophy, whose antiquity appears unpleasant. But what primarily obliged me to write in French, is the little the learnèd [gens d'estudes] make of philosophy or Scholastic theology. ${ }^{41}$

Moreover, some of these authors did not think dry philosophical arguments or threatening comparisons with Calvinists sufficient for their purposes. In certain cases, they invested mundane genres like the dialog, the conversation or the letter to a friend, and they imagined pleasant fantasies or picturesque narratives, sometimes manipulating with ease the polemic tools of satire and parody. To Fontenelle's Entretiens sur la pluralité des mondes (1686), where a Cartesian narrator instructs a marquise in natural philosophy, Father Daniel responds with Voyage du monde de Descartes (1690), where the narrator, disconcerted by the various accounts he has heard about the newly discovered Cartesian world, sets his mind to visiting it, as well as other worlds forged by philosophers, which he succeeds in doing thanks to an old man who knows Descartes' recipe to separate ones soul from one's body through the inhalation of some special tobacco. ${ }^{42}$ In a similar way, to the Requeste des maîtres es arts

\footnotetext{
${ }^{41}$ La Grange, Les principes contre les nouveaux philosophes, Preface, § 47, pp. 43 f. Azouvi, Descartes et la France, pp. 55-57, notes moreover that Cartesians like Cordemoy (Discours physique de la parole, 1668), Louis Le Laboureur (Avantage de la langue françoise sur la langue latine, 1669) and François Charpentier (Deffence de la langue françoise, 1676) explicitly argued that French was the language of philosophy par excellence.

42 The prefaces of these works show the similarity of their motivations, see Fontenelle, Entretiens sur la pluralité des mondes, Preface, pp. 9 f.: "J'ai voulu traiter la Philosophie d'une manière qui ne fût point philosophique; j'ai tâché de l'amener à un point où elle ne fut ni trop sèche pour les gens du monde, ni trop badine pour les Savans"; Daniel, Voyage du monde de Descartes, Avis, p. *4: "J'ai tâché de varier, \& d'égaïer un sujet aussi mélancolique, et aussi sec, que le peuvent être des matiéres de Philosophie, tant par la diversité des incidents..., \& même par quelques conversations assez animées de gens, qu'on ne sera pas fâché d'entendre parler." To these works, one might be tempted to add Huet's Nouveaux mémoires pour servir à l'histoire du
} 
imagined by Boileau, Bernier and Racine (1671) Daniel responds with Histoire de la conjuration faite à Stockholm contre Monsieur Descartes (1693) (added as an appendix to his Suite $d u$ voyage...). Written in a pedantic legal language the Requeste is a parody of what the teachers of the University of Paris might have said to the parliament in 1671 against the introduction of new ideas in physics, here the Court of Parnassus, followed by the arrêté pronounced by this Court: among many things, each one more absurd than the other, it prohibits blood from circulating in the human body, sends to the heart the injunction to continue being the principle of the nerves, reestablishes into their rights entities, identities, petreities and polycarpeities. ${ }^{43}$ Now, in the Histoire de la conjuration, all the scholastic entities are gathered in Stockholm to sue Descartes, who is accused of having denied their existence. At the beginning of the trial, motion plays the role of advocate for Descartes, but when he understands that, according to his client, he is only a mode, he resigns. Being definitively isolated, Descartes is condemned by the whole assembly as novateur and chief of a sect, a rebel with regard to the laws of the old and true philosophy, enemy of all kinds of scholastic entities, and finally sentenced to death. ${ }^{44}$ I have summarized only the most coherent and consequent writings, but, as we will see, this jesting mood animates most of the works here at stake, even those that were still written in Latin and occupied heavy tomes.

Second, as far as the content is concerned, there was a back and forth between natural philosophy and theology. As already noted, the new philosophers ventured to move to the somewhat slippery theological ground when they proposed mechanical explanations of the Eucharist. Moreover, in reaction to the accusations of defending opinions dangerous for

cartésianisme: in his letter to Bossuet of 5 April 1692, in Bossuet, Correspondance, vol. V, pp. 108 f., Huet writes that his book was inspired by Daniel's Voyage du monde de Descartes. However, contrary to Daniel's work, his Nouveaux mémoires is a fanciful biography with no explicit philosophical argument, in which Descartes, disappointed by Queen Christine, stages a fake death, travels here and there, and finally ends up teaching philosophy to the Lapps, to whom he bears great resemblance because of his small stature, big head, dark hair and swarthy complexion. In this respect, it should rather be read as an answer to Baillet's biography.

43 Boileau et al., Requeste des maîtres es arts, pp. $237 \mathrm{f}$.

44 “Et les voix ayant été recueillies, ce Philosophe infortuné fut déclaré Novateur et Chef de secte, Rebelle aux Lois de l'ancienne et veritable Philosophie; perturbateur de l'ordre des Categories: Ennemi des Vertus \& Facultez occultes; des Accidens absolus, \& non absolus; des Qualitez premieres, \& secondes; des Formes, des Elemens et des Mixtes; des Ames materielles, soit vegetatives, ou sensitives; des Instincts, substances incompletes, et generalement de toutes les Formes tant substantielles qu'accidentelles" (Daniel, Suite du voyage du monde de Descartes, p. 245). 
religion, they sometimes argued that substantial forms lead to licentiousness or paganism. ${ }^{45}$ Conversely, however, the defenders of the old philosophy did not always entrench themselves in theological citadels. To be sure, some of them, in particular Louis Le Valois and CharlesJoseph de Troyes, considered that it is sufficient to recall that faith is the rule of truth and what the truths of the faith are. Others however did not content themselves with asserting the precedence of truths of faith over truths of reason, they set to refute the Cartesian theses qua theses of natural philosophy as well, whatever their competence in this domain. ${ }^{46}$ Many physical questions were thus examined, from the question of what it is possible for God to create, to the adequacy of the Cartesian explanations of light, magnetism or tides, through the plurality of worlds or the genesis of the three elements.

In the following sections of this paper, I shall examine neither the questions pertaining to metaphysics, nor the questions pertaining to particular or special natural philosophy, but rather concentrate on two correlated questions pertaining to what was at this time called general natural philosophy, namely, the question of what kind of ontological entities are necessary for the establishment of a good physics, and the correlated question of what norms should be adopted in natural philosophy. The first question will lead me to focus on substantial forms in general and animal souls in particular, these scholastic entities par excellence. To use once again Father Daniel as a guide, "the article on substantial forms is the one that caused the most uproar and division between the two parties. ${ }^{47}$ In the France of this period, you belonged to the camp of old philosophers if you thought that substantial forms are necessary in physics, and to the camp of new philosophers if you thought that there are not. ${ }^{48}$

\footnotetext{
45 See infra, Conclusions.

46 Thus, they responded to the criticism of Rohault, Entretiens sur la philosophie, pp. $106 \mathrm{f}$.: "[C]ette Doctrine de M. Des Cartes, a esté depuis peu attaquée, par des personnes qui croyent avoir droit, sous pretexte de nouveauté, de s'opposer à tout ce que l'esprit peut découvrir dans les choses Naturelles. Ces personnes ne la combattent point par des raisonnemens philosophiques, et ils s'imaginent qu'il est bien plus aisé de la décrediter en exposant simplement qu'elle est contraire à la Religion” and his following injunction to examine Descartes' doctrine from a purely philosophical point of view.

${ }^{47}$ Daniel, Voyage du monde de Descartes, p. 143. Daniel has a deep concern with the characterization of philosophical sects; as we will note infra note 102, he characterizes more specifically the Cartesians by the exclusion of animal souls, and it was indeed a point on which they disagree with their fellows in innovation, the Gassendists.

48 There is no such statement with exceptions that confirm the rule; the most interesting exceptions are Fabri in the camp of old philosophers (on his requalification of substantial forms, see Roux, "La philosophie naturelle d'Honoré Fabri," pp. 87-90) and Leibniz in the camp of new philosophers.
} 
But be aware that this ontological question cannot be dissociated from the second one: with respect to which kind of norms were these entities excluded or, on the contrary, defended?

These questions are not totally unprecedented. In a series of seminal papers, Keith Hutchison systematically confronted the old Scholastics with the new Mechanical Philosophers, arguing that the incentive of their disagreement was not the methodological concern of the latter to avoid the vacuous explanations of the former, but their competing worldviews, in particular with respect to the questions of what should be considered as a cause and what should be considered as a physical entity. ${ }^{49}$ I shall not discuss here the details of Hutchison's argument. I do agree with his methodological attempt to render justice to the old philosophers, rather than to put them away on a back shelf. But I do not think that we have to decide whether the bone of contention was whether certain explanations were vacuous or whether they were false: both assertions were at stake. Moreover, as explained, I think that it might be fruitful to study an actual confrontation, in other words to consider a set of books that explicitly refer and respond to one another. In order to understand this confrontation, I will now review the fairly well-known arguments that were formulated by new philosophers against the ancients and thus make precise what exactly the latter were responding to. Only then will I isolate the generally lesser-known arguments of the ancients. Finally I will reflect on what we can conclude from this confrontation.

\section{ON THE SIDE OF THE NEW PHILOSOPHERS}

According to the longest lists mentioned above, Descartes, Gassendi, Maignan, Cordemoy, Rohault, La Forge, Lamy, Bernier, Cally, Malebranche, Arnauld and Régis were considered as new philosophers in the France of the years 1670-1690. In this paper, I shall exclude Descartes, Gassendi, Maignan, Bernier and Cally and restrict myself to studying Cartesians who published during the years 1670-1690, including minor figures like Nicolas Poisson, Bernard Lamy or Claude Gadroys. ${ }^{50}$ My aim is indirect and negative: I do not want to examine the ontological entities and physical norms defended by the new philosophers as such, but rather, the criticisms they addressed to the ontological entities and physical norms of the old philosophers; and I do not want to determine if these criticisms were correct or

\footnotetext{
${ }^{49}$ Hutchison, "What Happened to Occult Qualities in the Scientific Revolution," "Dormitive Virtues, Scholastic Qualities and the New Philosophies" and "Individualism, Causal Location and the Eclipse of Scholastic Philosophy."

${ }^{50}$ Their biographies are known thanks to the impressive work realized by Pierre Clair and François Girbal.
} 
pertinent, but rather, to understand the kind of natural philosophy their proponents were opposed to.

It is to be noted that, when they speak of old philosophers, new philosophers use generic designations, as if dealing with a litter of young animals, among which it is neither important to make differences nor to set precedence; a position is neither specified by nor associated with the name of a philosopher, the title of a book or the number of a paragraph, it is presented as a generic position defended in the "ordinary" or "common" philosophy. ${ }^{51}$ This type of designation suggests that the new philosophers do not take into account the differences that were significant to the eyes of the old ones, and that in so doing, they may oversimplify some real conceptual problems. Indeed, the new philosophers systematically characterize substantial forms as entities separated from matter, whereas, to the old philosophers, this was only one option among several available. ${ }^{52}$ Hence, one sees that it is one thing to establish that, according to the new philosophers, substantial forms were in an illegitimate way credited with a separate existence, and quite another to establish that it was indeed the case that substantial forms had a separate existence. In what follows, it is only the first of these that interests me.

But even if one keeps this clarification in mind, the criticism of the old philosophers often takes a form so grotesque that one gets the feeling of a paradigm shift, as if the new philosophers could not understand the natural philosophy of the ancients anymore, this philosophy being truly incommensurable to theirs in its objectives and in the means it used to achieve them. One can nonetheless identify three factors that enter into this critique, not clearly separated from each other: the entities of the old philosophers are unnecessary, the explanations they offer are trivial or even vacuous, the words they use are unclear or even meaningless. I shall consider these three reasons in turn. Overall, the charge made by the modern philosophers is serious enough to make one wonder what, according to them, forced

51 Rochon, Lettre d'un philosophe à un cartésien de ses amis, § 77, pp. 178-181, reproaches the new philosophers precisely for speaking of the School in general, and he insists that some distinctions should be introduced between different Aristotelianisms.

52 Rohault, Traité de physique, I, chap. 18, § 2, vol. I, pp. 141 f.; Malebranche, De la recherche de la vérité, VI, II, chap. 2, p. 642; Arnauld and Nicole, La logique, III, chap. 18, p. 240; La Forge, Traité de l'esprit, chap. 13, p. 206. According to Gilson, Études sur le rôle de la pensée médiévale dans la formation du système cartésien, pp. 162-163, the criticism does not concern essential forms as such (which can be designed, but not exist in a separate state), but essential forms as they are apprehended within the framework of Cartesian noetics (for which any true idea is the idea of a substance); for a detailed examination of separate forms in Scholasticism, see Des Chene, Physiologia, pp. 53 f., 65, passim. 
the old philosophers to adopt such a way of thinking infused with redundancy, triviality and vacuity. We shall see that the new philosophers also had an answer to this second-order question.

\section{The methodology of ontology: beings should not be multiplied without necessity}

The heart of the new philosophers' argument is here that the entities relied on by the old philosophers are superfluous. Once one accepts matter and its modes, figure and motion, substantial forms are no longer necessary to account for natural phenomena. According to the new philosophers, the old philosophers thus made use of superfluous entities, violating the principle of ontological economy by which one must never unnecessarily multiply beings. Here is a concise formulation of this idea by Cordemoy: "To reasonable people who know that one must not multiply beings without necessity, it is enough, in order to believe that it [a watch] has none [substantial form] to see that everything that it does can be explained by the body." ${ }^{, 53}$ Insofar as the body having such and such material configuration is sufficient to explain all the properties of a watch, one need not refer to a form that would add to them in order to understand these properties. One may well nominally call "form" the body as it has such and such material configuration, but this does not justify adding a new entity. The bogeyman of the unnecessary multiplication of entities does not only concern substantial forms, but is also used at several steps of the analysis. Thus, to each newly discovered property of a body, the old philosophers would have matched a new being, and thus increased the entities, if not unnecessarily, at least without restriction. ${ }^{54}$ In this way they derided the way the Aristotelians would have analyzed the concrete changes, even trivial, of the bodies that surround us: a new being corresponding to each new state of the body. To explain a trivial transformation, one must constantly bring about a multitude of new beings that follow

\footnotetext{
${ }^{53}$ Cordemoy, Six discours sur la distinction et l'union du corps et de l'âme, pp. $122 \mathrm{f}$. The same example is used by Malebranche, De la recherche de la vérité, III, II, chap. 8, § 2, pp. 357 f.

${ }^{54}$ Malebranche, De la recherche de la vérité, III, II, chap. 8, § 1, p. 355: "[V]oici ce qui arrive ordinairement aux philosophes. Ils voient quelque effet nouveau: ils imaginent aussitôt une entité nouvelle pour le produire.... [I]ls donnent libéralement au feu autant de facultés ou de qualités réelles, qu'il est capable de produire d'effets différents"; ibid., VI, II, chap. 2, p. 642: “Les philosophes... prétendent qu'il y a... une infinité de petits êtres...: et ils en supposent d'ordinaire autant qu'ils ont de différentes sensations des corps, et qu'ils pensent que ces corps produisent d'effets différents."
} 
one another like characters in an enchanted ballet, when, for example, wheat becomes bread or when a dog passes from life to death. ${ }^{55}$

The way of physics: physics should explain phenomena, namely, give efficient causes The new philosophers also accuse the old philosophers of being all talk. The latter would rely on general principles, vague and indeterminate, unable to yield any new knowledge, and in the end, unable really to explain the phenomena. Here is, for example, what Cordemoy says about elasticity: "The entire School says that this is done by an elastic virtue, that is to say, in common language, that there is something that has the power or virtue of making a spring: but this does not explain this thing." ${ }^{, 56}$ The idea is well known: the explanations of old philosophers are trivial, vacuous and circular, because the explanans (e.g., elasticity) is only a general term derived from the explanandum (e.g., the fact that some bodies are elastic, i.e. have the capacity to come back to their original state after a deformation). Generality here is bad generality, because one associates with the particular phenomenon in need of an explanation a principle whose only characteristic is that it is the cause of this phenomenon. It is precisely the criticism Arnaud and Nicole address to Aristotle's physics:

[T] he main fault one can find there is not that it is false, but that, on the contrary, it is too true and that is teaches us only things that is it impossible not to know... after learning all these things, it does not seem that one has learned anything new, nor that one is better able to reason as to any of the effects of nature. ${ }^{57}$

Contrary to how it was in this physics, one must "descend to the particular." 58 Obviously, the question at this point is to know what means "give a reason for a natural

\footnotetext{
55 For the transformation of wheat, see Cordemoy, Six discours sur la distinction et l'union du corps et de
} l'âme, pp. 113 f.; Malebranche, De la recherche de la vérité, VI, II, chap. 2, p. 639; for the transformation of a dog, see ibid., I, chap. 16, § 4, p. 127.

56 Cordemoy, Six discours sur la distinction et l'union du corps et de l'âme, p. 123.

57 Arnaud and Nicole, La logique, Discourse II, p. 33. See as well La Forge, Remarques, in Descartes, L'homme, pp. 183 f.: “De dire aussi que c'est une Qualité du Corps ou une proprieté de l'Ame [that makes the heart beat], cela ne sert de rien pour expliquer ce que c'est; non plus que si demandant ce que c'est qu'un Elephant, on me répondoit que c'est un Animal d'Affrique"; ibid., p. 217-219; Malebranche, De la recherche de la vérité, VI, II, chap. 2, pp. 640 f.: “[L]es scolastiques parlent si généralement, qu'ils ne se hasardent pas beaucoup. Une qualité est ce qui fait qu'on appelle une chose d'un tel nom, on ne peut le nier...." 58 “[O]n ne s'arreste souvent qu'à des questions si abstraites \& si generales, que quand bien mesme tous les Philosophes seroient de mesme avis sur chacune, cela ne pourroit servir à expliquer en particulier le moiundre 
effect," "descend to the particular" - in other terms, to know what the new philosophers expect from an explanation. According to them, explaining a natural phenomenon means in general being able to find its efficient cause, to explain by what means and after what manner it comes about; for mechanical philosophers in particular, it amounts to showing what microscopic configuration of corpuscles could produce this phenomenon. ${ }^{59}$ Ancient principles are thus criticized for not being able to produce a specific natural phenomenon. To this criticism are linked two considerations, one relating to the abusive way in which the old philosophers would have used final causes, the other relating to their incapacity to predict some future effects.

First, old philosophers are accused of being satisfied with final causes. The new philosophers that I study here do not exclude them because of a metaphysical criticism on the type of assumptions one makes about the Creator when one speaks of final causes; more simply, they declare final causes to be insufficient to explain the phenomena. To do so, they use witty analogies: to be satisfied with final causes would be as ridiculous as to say that wood comes to Paris for fear of cold, or to explain the motion of a ship by its navigator's destination. ${ }^{60}$

Secondly, the new philosophers say that their mechanical explanations are predictive. To know how the phenomenon is produced is to know which microscopic corpuscular configuration can be its cause, so that he who knows this configuration will be able to predict yet unknown effects. When in this case, Rohault says, one is dealing with experiences that are

effet de la Nature; Cependant une science d'usage doit bien-tost descendre dans le particulier.... Car enfin raisonner toujours, \& ne raisonner que sur des choses aussi generales que celles sur lesquelles on raisonne ordinairement, sans descendre à rien de particulier, ce n'est pas le moyen d'acquerir des connoisssances" (Rohault, Traité de physique, Preface, n.p.); “si nous voulons ... dire quelque chose de plus que le commun, il faut se resoudre à descendre dans le particulier, nonobstant la coûtume des Philosophes, qui n'y descendent presque jamais, \& qui se contentent pour l'ordinaire de proposer plusieurs questions fort vagues, \& qui peuvent même passer pour superfluës, en ce qu'on n'en peut tirer aucune utilité" (ibid., I, chap. 18, § 1, vol. I, p. 141).

${ }^{59}$ On mechanical explanations, see McMullin, "Structural explanations"; Clarke, Occult Powers and Hypotheses, pp. 164-191; Gabbey, "Mechanical Philosophies and their Explanations."

60 “[D]e quelque façon qu'ils la [the expression “crainte du vide”] prennent, ils ne satisfont pas à ce que l'on demande; non plus que feroit un homme, qui estant interrogé comment le bois vient à Paris des Provinces éloignées, répondroit qu'il y vient par la crainte du froid: car ce n'est pas là répondre à la question; puisque c'est apporter la cause finale, au lieu de l'efficiente que l'on demande” (Rohault, Traité de physique, I, chap. 12, § 3 , vol. I, pp. 78 f.); “Seroit-ce assez (par exemple) pour expliquer le mouvement d'un vaisseau qui seroit porté tantost en Syrie, \& tantost en Affrique, de dire que le Pilote qui est dedans a dessein d'y aller, et qu'il a connoissance de la route qu'il doit tenir, ne faudroit-il pas outre cela qu'il sçeust parfaitement bien l'usage des instruments du Vaisseau, \& qu'il eust l'adresse de s'en bien servir en vrai Pilote \& le pouvoir bien conduire" (La Forge, Traité de l'esprit, chap. 4, p. 122). 
most useful for the physicist, these are experiences that reasoning "anticipates." ${ }^{61}$ On the contrary, the old philosophers, insofar as their principles would only restate the explanandum in general terms, not only do not explain effects, but also are unable to anticipate some still unknown effects. Here is for example what Malebranche writes in this respect:

Even if one knows that there is in fire a substantial form accompanied by a million faculties like those of heating, of dilating, of melting gold, silver and all metals, of lighting, of burning, of cooking, if one proposed to me this problem to solve, namely, if fire can harden mud and soften wax, the ideas of substantial forms and the faculties to produce heat, rarefaction, fluidity, etc. would do me know good to know if fire would be able to harden mud and soften wax.... The same goes for all general ideas: they are thus totally useless for resolving any question. ${ }^{62}$

\section{Ontological categories: the bipartition between body and soul should be respected}

Finally the new philosophers argue that while the old philosophers use obscure and meaningless terms, the entities they relate to cannot be conceived. These are two different criticisms, one about language and the other about ideas, but the new philosophers confound them de facto. ${ }^{63}$ The interlacing of these criticisms is such that obscurity and inconceivability are both reduced to an ontological question: according to the new philosophers, it is because the entities used by the old philosophers do not exist that the words they use are obscure and that they do not correspond to any conceivable idea. ${ }^{64}$ In a number of texts, it is difficult to

\footnotetext{
61 “[L]es experiences de la troisiéme sorte sont celles que le raisonnement previent, qui servent à justifier ensuite s'il est faux, ou s'il est juste; Ce qui arrive, lorsqu'aprés avoir consideré les effets ordinaires d'un certain sujet, \& formé une certaine idée de sa Nature..., nous venons par raisonnement à connoistre que si ce que nous croyons de sa Nature est veritable, il faut necessairement qu'en le disposant d'une certaine maniere, il en arrive un nouvel effet, auquel nous n'avions pas encore pensé” (Rohault, Traité de physique, Preface, n.p.).

62 Malebranche, De la recherche de la vérité, VI, II, chap. 2, p. 641.

${ }^{63}$ Rohault, Traité de physique, I, chap. 12, § 1, vol. I, pp. 77 f.: “[D]es paroles qui ne signifient rien que l'on puisse concevoir"; Malebranche, De la recherche de la vérité, VI, II, chap. 2, p. 640: “Aristote ... propose et résout toutes choses par ces beaux mots de genre, d'espèce, d'acte, de puissance, de nature, de forme, de facultés, de qualités, de cause par soi, de cause par accident. Ses sectateurs ont bien de la peine à comprendre que ces mots ne signifient rien"; ibid., Elucidation 12, p. 948: "C'est principalement dans les matières de physique qu'...on se sert de termes qui ne signifient rien.... Ce sont des termes vides de sens."

64 Ibid., p. 942: “Tout ce qui existe se réduisant à l'être ou aux manières d'être, tout terme qui ne signifie aucune de ces deux choses ne signifie rien; et tout terme qui ne signifie aucune de ces deux choses distinctement et en particulier, ne signifie rien de distinct."
} 
know whether obscurity and inconceivability are considered as signs of an incorrect ontology or, conversely, assuming the correct ontology is known, they infer that ancient philosophers use obscure terms and have no conceivable idea. ${ }^{65}$ In any case, the fact is that the new philosophers constantly refer to simple categorizations of beings: a being is either substance or accident, and then, either spiritual or corporeal. For the sake of brevity I henceforth only focus on the second categorization. The categorization of beings as soul or body is a strict partition: everything belongs either to the category of the soul, or to the category of the body. The reproach addressed to the old philosophers is thus that they do not respect this partition: they do not understand that these two categories cover the totality of beings (in other words, they affirm that some beings depend neither on body nor on soul), and they do not realize that this is a strict partition (in other words, they relate certain beings to both body and soul).

The first type of error with respect to the ontological bipartition, asserting the existence of beings that depend neither on the body nor on the soul, is denounced by La Forge, not directly in relation with his ontology, but indeed in relation to his theory of ideas - the presupposition being that something of which we cannot have any idea does not exist:

[U]ndoubtedly terms must seem obscure when no idea corresponds in one's mind to the meaning given to them. Yet we have the idea of only two sorts of beings, generally speaking, namely that which is extended, which we call body, and that which thinks, which we call soul. And starting from when one speaks of other beings, that can be related neither to one nor the other,... such as those beings that one calls substantial forms of bodies, real, impressed, intentional, occult, sympathetic, or specific quality, concoctive, retentive or expulsive faculty etc., it is impossible for any idea to correspond to them in the mind, or that that what one then says have any meaning one can conceive. ${ }^{66}$

The second type of error with respect to this ontological bipartition is, according to the new philosophers, to assert the existence of entities that are both body and soul, or at least to treat something as if it belongs to one of these categories when in fact it belongs to the other. In the exemplary case of sensible qualities, which soon to be called secondary qualities, the old

65 Clarke, Occult Powers and Hypotheses, pp. $167 \mathrm{f}$, chooses the first option and concludes that this criticism is doomed to failure, because it is relative to the ontological framework in which it is formulated.

${ }^{66}$ La Forge, Traité de l'esprit, Preface, p. 77. See as well Régis, Système de philosophie, Physique, VII, II, chap. 17 , vol. II, p. 631. 
philosophers are claimed to have the mistaken belief that the feeling that a body causes in us belongs to this body. A passage from Arnauld and Nicole illustrates this idea:

The soul, which saw that it was not by its will that its feelings were excited in it, but that it had feelings only when occasioned by certain bodies, as when it felt heat when approaching fire, was not content to judge that there was something outside itself that was the cause for its having these feelings, about which it would not have been mistaken, but it went beyond this, believing that that which was in these objects was entirely the same as the feelings or ideas that had been occasioned. And from these judgments it formed ideas, by transporting these feelings of heat, color, etc. into the very things that are outside of it. And these are these obscure and confused ideas that we have of sensible qualities, the soul having added its false judgments to what nature let it know. ${ }^{67}$

Thus, in a recurrent and insistent way the old philosophers project onto bodies sensible qualities that, in fact, exist only in mind. ${ }^{68}$

In the case of qualities such as gravity, horror vacui, or the capacity of a plant to grow, the criticism is different and, so to speak, reversed. The old philosophers are not accused of projecting onto bodies that which exists only in mind, but of interpreting properties of the body as if they were properties of the mind. Arnauld and Nicole describe this error when they reconstruct the way the old philosophers elaborated their concept of gravity. The starting point consists in two true ideas - there is something that falls, and there is something that is causing this fall. But following a hurried judgment arises a proposition that is not true: the cause of the fall is in the stone. Given the axiom that no body can move by itself, this proposition suggests that the cause of the fall is a being that exists in the stone while being distinct from it. Hence, the stone includes matter, which receives the motion, and a substantial form, which gives the motion and which is the cause of the fall. ${ }^{69}$ At this point, however, the old philosophers, assuming they accept the ontological bipartition between body and mind, would think of the substantial form as a mind: if they thought of it as matter, the

\footnotetext{
${ }^{67}$ Arnaud and Nicole, La logique, I, chap. 9, pp. $71 \mathrm{f}$.

${ }^{68}$ See Rohault, Traité de physique, I, chap. 23-27, §§ 1-2, vol. I, resp. pp. 217, 249, 264, 270, and 291;

Malebranche, De la recherche de la vérité, I, chap. 10-19, and VI, II, chap. 2, resp. pp. 89-139 and 636-639.

${ }^{69}$ Arnaud and Nicole, La logique, I, chap. 9, p. 77.
} 
substantial form would be part of the matter of the stone, therefore one would be right back in the situation one wished to avoid, namely the situation where a body moves by itself. ${ }^{70}$ Whether they accept this or not, the ancient philosophers are therefore led to think of gravity as a mind acting on the body, and thus once again to commit an error of ontological categorization.

\section{The social twist}

The new philosophers also had an answer to the question of what could possibly have made the old philosophers adopt such a system of thought replete with redundancy, triviality and emptiness: they denounce the learned contention of the old philosophers and their relation to the authority of Aristotle. If the old philosophers came to lose the taste for things themselves, to use empty words, to believe that they know something new when they use a new name, or that they had resolved a problem when they had multiplied entities, it is first because they wanted to cover up their ignorance, to appear more knowledgeable than they actually were, and to distance themselves from those they call ignorant or common people. Rohault for instance, criticizes the tendency for them to

be accustomed to saying in general that this effect is produced by a quality. For from this custom comes that of giving words as if they were reasons, and the foolish vanity of believing that one knows more than common people, when one knows words the common people don't know.... Indeed, what difference can there be between the responses of a peasant and a philosopher, if when each is asked, for example, why a magnet attracts iron, one says that he does not know the cause, and the other that it takes place by an a virtue and an occult quality? Is this not in good French saying the same thing with different words? And is it not visible that the entire difference between the one and the other is that one has enough sincerity to avow his ignorance, and the other enough vanity to want to hide it? ${ }^{71}$

\footnotetext{
${ }^{70}$ Ibid., IV, chap. 7, p. 322.

${ }^{71}$ Rohault, Traité de physique, Preface, n.p. The knowledge of peasants and the knowledge of ancient philosophers are constantly compared by Rohault, see for example Entretiens sur la philosophie, pp. 104 and 115. See as well Clerselier, in Descartes, L'homme, Preface, p. ii-ij; Arnaud and Nicole, La logique, III, chap. 19, § 3, pp. 246-247: “[I]ls s'imaginent en être plus savans pour avoir trouvé ce mot.” See as well Gadroys, Discours sur les influences des astres selon les principes de M. Descartes, Preface, n.p.: “[L]a Philosophie
} commune a des principes si foibles, qu'on n'en peu6tt tirer aucune conclusion.... C'est une science de mots; ce 
The other source of the faults of the old philosophers is the respect they have for Aristotle. In fact, the new philosophers describe the relationship of the old philosophers to Aristotle in two complementary ways. It is first a relationship of dependence: the old philosophers are criticized for having an undue respect for Aristotle and for being his friends rather than friends of the truth. ${ }^{72}$ Nonetheless, the relationship from the old philosophers to Aristotle is also described as a betrayal: according to the new philosophers, the ancients betrayed Aristotle by preferring his scholastic followers to him. The problem with the Scholastics is not only that they pale in significance beside Aristotle, but more essentially that they misunderstand the status of his physics. Aristotle had conceived physics as a logic or a dialectic, and, as such, it was valid, but his scholastic commentators took for physical reality what was merely logical or dialectical. ${ }^{73}$ His Arab commentators are moreover accused of having introduced unnecessary subtleties in physics. ${ }^{74}$ This strategy of dissociating Aristotle from his followers does not call into question the principle of authority; it is rather a way of

n'est pas une science de choses; elle remplit la bouche \& elle laisse l'esprit vuide"; Malebranche, De la recherche de la vérité, III, II, chap. 8, p. 355: “[O]n s'imagine savoir mieux que les autres, ce que toutefois on sait beaucoup moins”; ibid., VI, II, chap. 2, p. 640: “[O]n n'est pas plus savant qu'auparavant”; ibid., Elucidation 9, pp. 916-917; ibid., Elucidation 12, p. 948.

72 Arnauld and Nicole, La logique, III, chap. 20, b6, pp. 282-283; Rohault, Traité de physique, Preface, n.p.; Malebranche, De la recherche de la vérité, II, II, chap. 3, pp. 210-214.

${ }^{73}$ Poisson, Commentaire, V, p. 166: "[Matter and form] ne sont que des termes, qui de soy sont tres bons \& tres explicatifs des diverses manieres dot [sic] on peut considerer cet or ; mais qui n'ont jamais dû estre employez comme si c'estoit des choses réellement \& substantiellement existentes, n’ayant esté pris au commencement que comme des façons de parler”; Malebranche, De la recherche de la vérité, III, II, chap. 8, § 1, p. 356: “Si les philosophes ordinaires se contentaient de donner leur physique simplement comme une logique, qui fournirait des termes propres pour parler des choses de la nature..., on ne trouverait rien à reprendre dans leur conduite.... Mais... ils veulent absolument que la Physique de leur maître Aristote soit une véritable Physique, qui explique le fond des choses, et non pas simplement une logique."

${ }^{74}$ Lamy, Entretiens sur les sciences, pp. 253 f.: "Pour ce qu'il [Aristotle] dit de la Phisique en general, c'est plûtôt une Dialectique ou maniere de parler des choses naturelles, qu'une veritable Physique. Aussi il n'y a rien de mieux dit, ni de plus vrai que ce qu'il en écrit, quand on prend bien sa pensée. Ce qu'il dit de la matiere $\&$ de la forme n'est que pour marquer précisément que ce que l'on entend par ces noms.... Il en est de même de la quantité et des qualitez, dont il ne fait qu'expliquer ce que leurs noms signifient dans l'usage de la Langue.... Aujourd'huy..., ce n'est point proprement sa Philosophie qui règne dans les Ecoles, c'est celle des Arabes.” See as well Arnauld, Plusieurs raisons pour empêcher la censure ou la condamnation de la philosophie de Descartes, § 6, pp. 310 f.; Rohault, Entretiens sur la philosophie, pp. 115 and 152 f. Both Arnauld and Rohault refer explicitly to Rapin, on which see infra, note 118 . 
capturing Aristotle's prestige to the detriment of the old philosophers. If the old philosophers misunderstand Aristotle, their theses may well be incompatible with the theses of the new philosophers, while the same does not apply to Aristotle. ${ }^{75}$

The argumentation of these new philosophers is neither remarkable for its novelty nor its sophistication. On the contrary, one can easily show that regarding the substance of the matter, they merely adopt arguments, ideas or examples that could be found in the older generation, most notably in Gassendi and Descartes and beyond, in some Renaissance discussions. To conceptual sophistication and detailed discussion, they obviously prefer polemics, including swift satire and exaggerated simplification, possibly inspired by their performances in salons, conférences and private academies. Thus we might well wonder about the old philosophers being targeted in this way. In particular, we wonder if not some of them should have been a bit more subtle than Moliere's physicians invoking the "dormative virtue" of opium, if they could hear all of these critics without even trying to answer to them, and if they were all so firmly attached to the Aristotelian camp that they needed to hear yet again what had already been said fifty years earlier.

\section{ON THE SIDE OF THE OLD PHILOSOPHERS}

We may be at a loss when asking ourselves who exactly should be included in this group. To include those, who were classified as ancients by the moderns will not do; as already noted, whereas the ancients explicitly name the moderns that they wish to refute, moderns use generic designations when they castigate the "ordinary" or "common" philosophy. In the following, to delineate the hard core of ancients that I shall study, I use two criteria, one that pertains to the format (the typical book I am dealing with is a small format volume written in French for honnêtes gens) and another one which pertains to the content (the book should aim at refuting new philosophers). These two criteria do not always coincide during the period in question: on the one hand, there had been Aristotelian manuals written in French since the early seventeenth century; on the other hand, some refutations of new philosophers are written in Latin. Here I shall not consider the former, represented for example since the beginning of the century by the manuals and introductions to philosophy written by Scipion

\footnotetext{
${ }^{75}$ Rohault, Traité de physique, Preface, n.p., notes that his disagreement is not with Aristotle, but with his commentators.
} 
Dupleix, Pierre Du Moulin, Théophraste Bouju, Léonard de Marandé, Charles Sorel, Gilles de Launay or Louis de Lesclache. As a rule, I shall also exclude the typical products of the teaching institutions, such as manuals and theses, but also systematic refutations of Descartes written in Latin by professors who had published a manual earlier on, such as Pierre Godart or Jean Vincent, superior of the Congregation of Christian Doctrine in Toulouse. ${ }^{76}$

The hard core of the corpus obtained by applying these two criteria is composed of works written by Jesuits who would later obtain eminent positions in Paris: Ignace-Gaston Pardies, Antoine Rochon, Louis Le Valois, Gabriel Daniel, René Rapin. ${ }^{77}$ Considering the singular position of Honoré Fabri in the Jesuit institution and in the history of Cartesianism, some of his treatises will be mentioned as well. ${ }^{78}$ To them, I have added an Oratorian (JeanBaptiste de La Grange), because his book was the first attack on the new Cartesian school in this period, and a member of the high clergy (Pierre-Daniel Huet), because of the interest of his Censura philosophiae cartesianae. ${ }^{79}$ But I exclude the secular Jean Duhamel's further exchanges with Régis, simply because they would add nothing to my argument. ${ }^{80}$

${ }^{76}$ Godart's diptych is composed of his Totius philosophiae summa and his Dissertatio in qua egregie ludicra Cartesii revelantur. Vincent's diptych consists of Cursus philosophicus and his Discussio peripatetica in qua philosophiae cartesianae Principia ... examinantur.

77 To take them by alphabetic order, Gabriel Daniel (1649-1728) was the librarian, then the Superior, of the Parisian Jesuit maison professe and historiographer of France; Louis Le Valois (1639-1700) taught philosophy first at the Collège de Clermont in Paris (from 1682 on, collège Louis-Le-Grand), then in Caen for ten years, and was finally appointed confessor to Louis XIV's grandsons; Ignace-Gaston Pardies (1636-1673) taught philosophy and mathematics at the Collège de Clermont, but died too young to get any other position; René Rapin (1621-1687), professor of rhetoric at the Collège de Clermont, wrote extensively in prose and in verse; Antoine Rochon (1637-???), professor of philosophy in Bordeaux, prédicateur in Toulouse, finally quit the Jesuits for the Benedictines in 1685; it is said that Pardies polished up Rochon's Lettre d'un philosophe à un cartésien de ses amis. Arnauld, Plusieurs raisons pour empêcher la censure ou la condamnation de la philosophie de Descartes, $\S 1$, pp. 303 f., notes that this Jesuit mobilisation was no coincidence: “On dit que le général des jésuites a écrit une lettre circulaire à toutes les maisons de la Société, pour obliger les jésuites d'écrire partout contre la philosophie de M. Descartes."

${ }^{78}$ For a general presentation of Fabri's project in natural philosophy, see Roux, "La philosophie naturelle d'Honoré Fabri.” Brockliss, “Pierre Gautruche et l'enseignement de la philosophie de la nature,” p. 201, notes that Fabri's Physica being too long for the students, it was probably aimed at teachers: among these teachers were obviously the Jesuits here studied.

79 Jean-Baptiste de La Grange (1641-?) taught philosophy at Montbrison and Le Mans, then theology at Troyes; towards the end of his life, he was curé in Chartres; Pierre-Daniel Huet (1630-1721), preceptor to Dauphin with 
These old philosophers responded blow by blow, and often by turning their arguments back on the new philosophers, so the best way to proceed seems to consider once again the four topics identified previously. As we will show, the old philosophers, full of verve, succeeded in putting in place effective responses to their opponents: but by doing this, they helped to ensure the supremacy of the latter. There is no paradox here: rather, they had recognized the rules proposed by the new philosophers and now played the same game.

The methodology of ontology: the multiplication of corpuscles and the missing metaphysical supplement

The old philosophers give two distinct answers to the accusation that they multiply entities without necessity. First, they denounce the pretensions of the new philosophers, and assert that they are on the same footing as them. The new philosophers claim to have only three principles, matter, figure and motion, and thus to be more economical in beings than the old philosophers. In reality, they proceed exactly as do the old philosophers, because what explains this or that quality is not matter, figure and motion in general, but particular corpuscles with a particular figure and a particular motion. Perhaps old philosophers invented new forms and qualities each time that they had a phenomenon to explain; but, in such circumstances, new philosophers likewise invoke specific figures and specific motions without giving us any reason for this specificity, except their own pleasure. ${ }^{81}$ In other words, the ancients accept the principle that one must not multiply beings without necessity, ${ }^{82}$ but they assert that modern philosophers perform no better than they do when it comes to the

Bossuet (1670-1680), member of Académie française since 1674, was successively abbot of Aunay, bishop of Soissons, bishop of Avranches, abbot of Fontenay.

${ }^{80}$ Jean Duhamel taught philosophy at collège du Plessis, attached to the Sorbonne; his polemic with Régis began in 1692 with his Réflexions critiques sur le système cartésien de la philosophie de M. Régis.

${ }^{81}$ Fabri, Physica, Auctor lectori, § 12, n.p. : “[C]um enim corpus, modò quiescat, modò moveatur, modò illo, modò isto motu, centies quaeram, cur \& unde sit ille motis; ergo motus principium non est: deinde innumeras atomos \& figuras agnoscunt, quarum tamen nulla ratio est; igitur gratis, ut aiunt, \& ex mera fingendi libidine, haec statuunt." See as well id., Epistolae tres de sua hypothesi philosophica, I § 23, resp. p. 52; id., CEuvres de Fabri, vol. IV, f. 208r.

82 That they admit this principle is confirmed by particular explanations, see for example what La Grange, Les principes contre les nouveaux philosophes, chap. $26, \S 9$, p. 374 , notes before giving his own explanation of elasticity: "Comme il ne faut point multiplier les Estres sans necessité, aussi ne faut-il pas avoir recours à aucune Forme Accidentelle, quand on peut expliquer les choses autrement.” See as well, ibid., chap. 41, § 2 , p. 518 . 
explanation of specific phenomena; they multiply the figures and motions of their corpuscles at will, in just the same way as the old philosophers used to multiply forms and qualities. It is even said that they do worse, insofar as they admit Descartes' thesis that any corpuscle can be changed in any corpuscle: according to Huet, it is impossible in these circumstances to attribute particular effects to particular corpuscles, in the way that particular effects are attributed to particular Aristotelian forms or to particular Epicurean atoms. ${ }^{83}$

Of course, one might ask just how pertinent these responses are. First, the relation of the notion of form in general to peculiar forms is not the same as the relation of matter to specific corpuscles: in the first case, it is a grammatical relation of subsumption; in the second case, it is a physical relation of specification. Second, the fact that corpuscles change over time does not mean that it is impossible to establish a relation of causality between a kind of corpuscle and some specific effects: the same amount of matter does not have the same effects when organized into different corpuscular configurations. In this paper, however, I do not want to discuss the pertinence of the arguments, but to show that there was an argumentative debate and to reconstruct its lines of force.

The second answer the old philosophers offer is different, but likewise does not contest the principle that beings should not be multiplied without necessity. Namely, this second answer amounts to restricting the application of the traditional catchphrase to ontologically determined domains. The multiplication of forms should not be considered a multiplication of physical beings, simply because forms are not physical beings, but metaphysical principles. With their first answer, the old philosophers claim to be on the same footing as the new philosophers; here, they assert that forms give them an advantage, namely metaphysical supplements that do not serve to explain phenomena in their specificity, but that constitute their metaphysical foundation. This is well expressed by Rochon, who, after having recalled that Aristotelians also used corpuscles in their explanations, describes the opposition of physics and metaphysics as an opposition between the exterior and the interior:

\footnotetext{
83 “[V]erum si attentius spectemus principia Cartesii, quam specie simplicia, tam multiplicia effectu comperiemus. Nam continua illa tritura partium, quae quantumvis comminutae magis magisque tenuari, ac propterea novas semper figures induere possunt... feracissima seges est ad quidvis comminiscendum.... Id autem Aristoteli aut Epicuro nequaquam possis objicere: nam cum hic certas figures immutabiles, certumque figurarum numerum individuis suis corpusculis adscripserit; ille vero ad certas formas definitas retulerit rerum omnium ortum atque statum, certi inde effectus \& definiti jure elici potuerunt." (Huet, Censura philosophiae cartesianae, chap. 8, § 3, pp. 171 f.).
} 
You can see, sir, that so far we are equal, and that your philosophy and ours are similar: the difference is that you stop there without going farther, and without even recognizing that there is something else in nature: whereas we believe that we would be stopping at the first surface if we did not seek to penetrate further to discover that beyond all that thus appears outside, there is yet inside something that is the principle of all these dispositions and all these effects, what we call form. ${ }^{84}$

That equals pulling the rug from under the feet of the new philosophers: if the forms of the ancients are not redundant in the explanation of phenomena, it is not because they are necessary, but simply because their function is not to explain phenomena, but to designate their essence.

The way of physics: one should not indulge in hypotheses, ignore experiments and use empty words

Contrary to what might be expected, against the reproach of not explaining phenomena because they ignore efficient causes, as a rule, the old philosophers do not defend final causes. They rather attack the new philosophers because, devoting all their time to the invention of probable hypotheses regarding corpuscles and motions that could cause this or that phenomenon, they overlook the experiences of both common sense and the new sciences, without providing us with any new knowledge.

New philosophers intended to find explanations that could reduce phenomena to their corpuscular causes, but since these corpuscular causes are not subject to observation, they are hypothetical and probable in a context where science (scientia) was still equated with absolute certainty. Old philosophers insist that corpuscular causes are only probable, just hypotheses, simple fictions. ${ }^{85}$ Moreover they deride with verve the different strategies of the

\footnotetext{
${ }^{84}$ Rochon, Lettre d'un philosophe à un cartésien de ses amis, §§ 59-60, pp. 142-144. See as well ibid., § 66, p. 154: “[V]ous ne ferez que repeter ce qu'enseigne Aristote. Mais souvenez-vous qu'outre cela Aristote reconnoit des Qualitez et des Formes que vous ne connoissez pas, \& qu'il n'avouera jamais que l'odeur ou la chaleur soient ces vapeurs ou ces pyramides."

85 La Grange, Les principes contre les nouveaux philosophes, Preface, § 27, p. 24; Pardies, Discours de la connaissance des bêtes, § 110, pp. 210 f.; Huet, Censura philosophiae cartesianae, comments the Cartesian fable concerning the origin of the world, "Haec... miracula, non disserentis Philosophi, sed somniantis; non docentis, sed optantis..." (chap. 6, $§ 2$, p. 154) and picks up ironically the Cartesian expression fabula mundi (p. 158).
} 
Cartesians to pretend that they could bypass the "only probable" character of their hypotheses. ${ }^{86}$ Huet, for example, compares the Cartesian asserting that he can explain the probable origin of the world to a man seated at the gates of Paris who would explain to travelers that they came from one city or the other, simply because it could have been the case that they actually came from one city or the other city. ${ }^{87}$

It is known that in their teaching the Jesuits at least made way for new observations and experiments that were performed in the first half of the century ${ }^{88}$ in the polemical texts that I am here dealing with, tribute is indeed paid to the experimental philosophy that would have been that of Galileo. ${ }^{89}$ The point to understand is that when experience is contrasted with hypothetical reasoning, this concerns both sensory experience and the scientific experiment. Indeed, what is first at stake here is to rehabilitate the sensible qualities and to rely on common sense. Everyone knows that light is spread around the world, a diamond is hard, that snow is white, that fire has heat, and here are the Cartesians telling us "what vulgar philosophy calls sensible qualities, are no accidents of bodies, but are rather modes of our soul, that is to say, real thoughts that we have when encountering objects that present themselves to our. ${ }^{90}$ Who then will believe them? As systematically as Rohault stresses for each quality that the same word (e.g., "heat") could mean both the feeling (e.g., the heat that I feel) and the physical cause of this feeling (e.g., some corpuscles able to cause this heat), La Grange distinguishes the feeling from the physical cause of this feeling for a number of

\footnotetext{
86 On the hypothetical character of corpuscular causes, see La Forge, Remarques, in Descartes, L'homme, pp. 216-218; Rohault, Traité de physique, I, chap. 3, § 3, vol. I, pp. 22 f.; Poisson, Commentaire, VI, pp. 173-195; Gadroys, Discours sur les influences des astres selon les principes de M. Descartes, chap. 10, pp. 216-218; Lamy, Entretiens sur les sciences, pp. 257-261; Régis, Système de philosophie, Physique, I, Avertissement,
} vol. I, pp. 274 f.; id., Réponse à Huet, chap. 8, § 3, pp. 304-306. For an analysis of the Cartesians’ ambivalence towards hypotheses, see Clarke, Occult Powers and Hypotheses, pp. 131-163, 228-231, passim.

87 "Nam si vel aliam caussam [sic] habere potest hic effectus, vel alium effectum habere postest caussa [sic] isthaec, hunc ex illa arcessere, divinare est.... Quam ineptus vero ille sit ridiculus qui sedens ad Lutetiae portam, profiteatur se dicturum unde viatores omnes illuc adventantes sint profecti; hunc Lugduno illum Divione dicat profectum; quia hic Lugduno, ille Divione proficisci potuit?" (Huet, Censura philosophiae cartesianae, chap. $8, \S 3$, pp. 169 f.).

${ }^{88}$ Brockliss, "Descartes, Gassendi, and the Reception of the Mechanical Philosophy,” pp. 454-456; id., "Pierre Gautruche et l'enseignement de la philosophie de la nature," pp. 190-194, 199, 209-216.

${ }^{89}$ Rapin calls Galileo the "Father of Modern Philosophy" (Réflexions sur la philosophie, $\S 18$ p. 365) and the "Founder of Modern Philosophy" in Italy (Réflexions sur la physique, § 9, p. 450).

${ }^{90}$ Pardies, Discours de la connaissance des bêtes, $\S 7$, pp. 10-13, and pp. 12 f. for the quotation. 
qualities. For him the point is not to assume that one can assimilate the feeling and its physical cause, or jump from the one to the other, but in case of heat, he explains that a series of reasonings makes it possible to attribute some heat to fire:

[T]he Peripatetians do not draw their conclusion that fire is hot from the fact that it produces heat in the hand,... because it is not always necessary that a cause be like its effect. But they conclude that fire must necessarily be hot, because it generally heats all sorts of bodies, however different and opposed they may be, which is very well: because... when an efficient cause produces the same effect in an infinite number of different materials, the production of the effect cannot come from the disposition of the material, since the materials are different and the effect the same. This is why we are obliged to say then that the cause is like its effect. ${ }^{91}$

No ingenuity here, rather the will to reason so as to make a difference, in the sense, between what belongs properly to the body, which seems to be the origin of a particular feeling and what belongs either to the person, who actually has this experience, or to other bodies. Although this is not the place to go into detail, one can note that the purpose of Fabri's Physica was to establish a physics more geometrico, taking basic qualities (dry and wet, tense and compressed, heavy and light) as first principles endowed with such certainty that it would not be necessary to use any hypothesis whatsoever. ${ }^{92}$

Finally, the inability of new philosophers of taking the experimental character of the new science serious is underlined. Rochon notes for example that, once again, moderns pretend to more than they are actually able to accomplish. They pretend that they can anticipate the outcome of experiments (prévenir les effets de la nature), but the best that they can do is to retroactively predict this outcome when the experiment has already been performed. In this, they are similar to Cardano, who wanted to defend and illustrate his rules in astrology by drawing up the horoscopes of the dead. When he tried to extend his computations to future events concerning the living, what actually happened obliged him to resume his computations to adapt them to the actual events, once again retroactively. ${ }^{93}$

\footnotetext{
${ }^{91}$ La Grange, Les principes contre les nouveaux philosophes, chap. 34, § 1, pp. 452 f.

92 On Fabri's project, see Roux, “La philosophie naturelle,” pp. 90 f.

93 “Il est vray que vos Messieurs font merveilles quand ils peuvent attraper une experience qu'ils ont faite cent fois pour en estre bien assurez. C'est alors qu'ils sont heureux à faire voir la beauté de leur doctrine en prevenant, disent-ils, l'experience, \& en faisant voir ce qui doit suivre de leurs principes. Cela s'appelle deviner
} 
Considering what mechanical explanations had turned out to be in the hands of the Cartesians, the most pervasive and pertinent criticism consists in observing that they have no more informational content than their ancient counterparts. Namely, if the explanation of a given phenomenon is to say that certain corpuscles animated by certain motions produce this phenomenon, its informational content is no more determinate than the informational content of the assertion that a substantial form is what makes a given body what it is. It is Rochon whom I would like to follow in this respect. He first recalls the argument of the new philosophers that Aristotelian qualities, virtues and forms do not bring any new knowledge. ${ }^{94}$ In reference to that argument Rochon shows in the specific instance of the growing of plants that neither do the Cartesian explanations add anything new to common knowlegde:

Everyone knows that plants have fibers and pores by which the juices penetrate and then form all the parts of the plant... If you say that in the School one says these things only in general and in a vague fashion, without explaining in particular, we say to you that you do the same. Everything you say gives no knowledge of the particular and of what is in fact in a plant. You content yourselves by saying that the pores are arranged in a certain manner, that they are of a certain figure, that the parts that conform to certain openings pass through, and that others are stopped. You try to get off with "a certain." But if I ask you what this certain figure is, and what the certain manner and what is this certain juice and these certain parts, you have nothing to say other than that you know no more. What more are you saying than the per intus susceptionem of ordinary philosophers? ${ }^{95}$

tout ce que l'on voit \& predire exactement le passé. Je n'entends jamais parler de cét avantage qu'ils se donnent de prevenir ainsi les effets de la nature, que je ne me souvienne de ce qui arriva autrefois à Cardan" (Rochon, Lettre d'un philosophe à un cartésien de ses amis, § 85, pp. 197-198). "Prévenir les effets de la nature" is what Rohault pretended to do with his third sort of experiment, see supra, note 61; Cardan's horoscopes are also scoffed at by Daniel, Voyage du monde de Descartes, pp. $138 \mathrm{f}$.

94 “[V]ous avez oüy dire cent fois à vos Messieurs que dans la Philosophie de l'ecole on n'enseigne rien de la nature, qu'Aristote ne dit rien que ce que tout le monde sçait déja, qu'on répond à toutes les questions par une Qualité, par une Vertu, par une Forme, qui ne donnent aucune nouvelle connoissance: au lieu que Monsieur Descartes passe bien plus avant: qu'il explique les choses comme elles sont en elles-mesmes: qu'il fait entendre leur nature et qu'il rend raison de tous leurs effets" (Rochon, Lettre d'un philosophe à un cartésien de ses amis, $\S 50$, pp. 128 f.).

95 Ibid., $\S 59-60$, pp. 140-144, and pp. 142 f. for the quotation. 
Like the moderns laughing at the ancients because they are unable to explain the transformation of flour into bread or the transition from a living dog to the cadaver of a dog, and pointing out that Descartes had challenged the Jesuits to find an issue on which his philosophy would not be more satisfactory than the philosophy of the School, Rochon challenges a whole assembly of Cartesians at the end of his book to explain the simplest thing, the formation of a pumpkin in a single night. His prognosis is, as one might guess, that they will be unable to do better than to parade once again with their "certain ways," "certain motions," and "certain figures." 96 Therefore, here the criticism does not bear on the mechanical explanations considered in their principle, but on what were in fact a number of them. In their desire to supplant the ancient philosophers and to show that they were able to explain absolutely every phenomenon, the Cartesians often merely asserted that a mechanical explanation of a given phenomenon should be possible, provided one assumed the adequate corpuscles and the appropriate motions. So they came to offer explanations as empty, circular or tautological as the explanations they blamed the old philosophers for. In this sense, it is no wonder to find this criticism of Rochon in Pardies, ${ }^{97}$ La Grange, ${ }^{98}$ Rapin ${ }^{99}$ and Daniel ${ }^{100}$ It

${ }^{96}$ Ibid., § 84, pp. 194-196.

97 “C'est une chose admirable que tous ces Philosophes qui nous reprochent perpetüellement que nous voulons les payer de mots qui ne signifient rien, \& que nous leur répondons à toutes leurs demandes par une Vertu, ou par une Forme, pensent nous donner un grand éclaircissement sur ce sujet, en nous disant ce qu'ils disent à toutes les questions, que ce sont de certains atomes, de certains esprits, ou un certain feu, qui assûrément ne sont que des mots aussi vagues que le sont ceux de formes ou de vertus, \& qui ne nous donnent pas plus de lumière pour voir le détail des choses, que font les qualitez occultes" (Pardies, Discours de la connaissance des bêtes, § 100, p. 188).

98 “'Lors qu'il s'agit d'expliquer la nature de quelque Qualite corporelle, le party des cartistes paroist assés fort pour tenir teste aux Peripateticiens: Ils ont recours à la disposition des parties, comme à un azile tres-assuré; si les corpuscules quarrés ne leur sont pas propres, ils prennent les pointus $\&$ les crochus, \& dans une necessité, ils les font courir les uns aprés les autres, de sorte qu'on a toutes les peines du monde à les attraper" (La Grange, Les principes contre les nouveaux philosophes, chap. 3, p. 65).

99 “Et quand, pour rendre raison des choses, il [Descartes] a dit qu'elles se font par une certaine figure, par un certain mouvement, par une certaine extension, il a tout dit” (Rapin, Réflexions sur la physique, § 10, p. 455). 100 “[L]es Péripatéticiens disent que toute la difficulté consiste à expliquer les choses en détail, qu'il n'y a que ce détail qui leur fait de la peine; que si vous vouliez bien leur faire comprendre cette certaine manière, cette différente manière que vous nommez si souvent et que vous n'expliquez jamais, ils seraient aussitôt à vous.... toute la science des Cartésiens en cette matiére se réduit à nous assurer que Dieu est tout-puissant et qu'il peut exécuter l'idée très-confuse, qui leur est venuë à l'esprit, d'une machine de chair \& d'os, qui feroit par 
might be fitting to conclude with the condemnation of Descartes in Daniel's Histoire de la conjuration:

[A]fter having led us to believe that he would explain everything in an easy and natural manner, he [Descartes] only explains physical effects by certain elements, certain assemblies of parts, certain movements and certain figures; that is hardly different from certain entities, certain forms, certain virtues, and certain qualities, and after all, by rights of seniority, the scholastic I know not what should win out over the Cartesian I know not what. ${ }^{101}$

\section{The ontological categories and the controversy over animal souls}

There were two distinct ways to counter the ontological bipartition between souls and bodies: either to display beings that are neither body nor soul, or to display beings that are intermediate between body and soul. The old philosophers took both paths, but the first was the most frequently used, especially when the old philosophers discussed animal souls. To use Father Daniel as a guide,

the essential point of Cartesianism, its touchstone,... is the doctrine of the automata, which makes pure machines of all animals, by taking from them all feeling and all consciousness.... This single point includes or supposes all the principles and bases of the sect.... Here is the spirit and the essence, if I can speak this way, of pure Cartesianism. ${ }^{102}$

Indeed, the question of the soul of the animals involved issues well beyond the case of animals: first, what was psychologically at stake was to defend the idea that there is certainty in the senses distinct from the certainty of the mind and thus, in continuity with the questions

le moyen de ces ressorts ce que nous voyons faire aux bestes" (Daniel, Suite du voyage du monde de Descartes, pp. 43-46).

101 Ibid., p. 230.

102 Ibid., pp. 3 f. The thesis that animal souls are superfluous and even, considering the bipartition of bodies and souls, impossible, is expressed by Cordemoy, Six discours sur la distinction et l'union du corps et de l'âme, pp. 205 f., 266 f.; Arnauld and Nicole, La logique, III, chap. 13, pp. 224-226; Poisson, Commentaire, V, pp. 147168; Rohault, Entretiens sur la philosophie, pp. 138-152; Malebranche, De la recherche de la vérité, IV, chap. 11 and VI, II, chap. 7, resp. pp. 467-469 and $713 \mathrm{f}$. 
dealt with in the preceding paragraph, to defend the idea of knowledge based on observations and experiments. But the question of animal souls was also, and perhaps mostly, a way of defending an ontological point of view, for to confer a soul on animals is to admit that there exist more than two species of beings, or at least that there exists what Daniel calls "intermediate beings," that is to say, beings that partake of both the material body and the immaterial soul. ${ }^{103}$

The most elaborate argument in this respect is Pardies' Discours de la connaissance des bêtes. ${ }^{104}$ The first part set out the Cartesian arguments against the existence of animal souls so clearly that Pardies was accused by some of his fellows of being a cryptoCartesian. ${ }^{105}$ In the second part however, Pardies presents a rigorous defense of animal souls. As a first step, Pardies proceeds psychologically: he seeks to establish the existence of a purely sensible knowledge, distinct from the intellectual or spiritual knowledge, by which we know that we know, something that implies reflexivity. ${ }^{106}$ Thus, seeing is not only a physical process, since all the physical phenomena that accompany vision may occur in an artificial eye. ${ }^{107}$ But that does not make seeing an intellectual process, since we can see without knowing that we see, that is, according to Pardies, with no consciousness that we see, with no attention to this perception, with no reflection about it. The most telling example taken to illustrate this purely sensible vision is the reading of a book: when we read, we see the characters, but we pay no attention to them, since we are unable, in general, to say if they

\footnotetext{
${ }^{103}$ Daniel, Suite du voyage du monde de Descartes, p. 83.

104 The argument is less tight in Grange, Les principes contre les nouveaux philosophes, chap. 24, pp. 339-354, and Daniel, Suite du voyage du monde de Descartes, pp. 83 f., but identical in its principle: to establish a distinction between thought and reason, or between sensible knowledge and reasonable knowledge, which has the same effect as Pardies' distinction between mere perception and perception of oneself, namely, to assign to animal and to man two operations that are independent one from the other.
}

105 On this, and for a more thorough analysis of Pardies' position, see Roux, "Pour une conception polémique du cartésianisme."

106 Pardies, Discours de la connaissance des bêtes, § 78, pp. 150 f.: "La connoissance spiritüelle, ou, si vous voulez, intellectüelle, est... une perception qui emporte essentiellement avec une espece de réflexion qu'elle fait invisiblement sur elle-même, en sorte que nous connoissons fort bien que nous connoissons. Mais la connaissance sensible est une simple perception d'un objet sans cette réflexion."

${ }^{107}$ Ibid., $\S 80-81$, pp. 155-158. See in particular ibid., $§ 81$, p. 158: “Car enfin, voir n'est pas recevoir des raions de lumiére, ni avoir une image de l'objet representée au fond de l'œil; voir, dit quelque chose de plus, puisque toutes ces representations optiques pourraient très bien se faire dans un œil artificiel." 
were well formed, or if they were roman or italic characters. ${ }^{108}$ The question at this point is to know what may be the ontological foundation of the sensitive knowledge that mere perception is, as distinguished from intellectual perception.

In a second step, Pardies once again asserts that, since it is distinguished from intellectual perception, sensible perception need not be associated with the mind. ${ }^{109}$ On the other hand, figures, arrangements of parts, dispositions,

none of this can enable us to understand how an animal could feel: we must then say that there is beyond all that some other principle, which we call form, and because these operations are not beyond corporal power, there is no need to say that this is a pure spirit, but rather that it may be a material form. ${ }^{110}$

Once the concept of material form is advanced, the third and last step is logically to show that this concept can be conceived, that is, that it is not contradictory; Pardies actually contents himself with showing that it is conceivable by his opponents. Indeed he proceeds ad hominem, noting that to explain the phenomena the new philosophers themselves need to admit the existence of motion, which is neither a bodily substance, nor a spiritual substance, but a mode of the body. ${ }^{111}$ In the same way, the ancient philosophers would be entitled to admit substantial forms, which, "being neither bodies, nor modes, nor accidents of bodies, are nevertheless something corporeal," namely, in the case of animals, this something that makes us say of them that they are, precisely, animated. ${ }^{112}$

\section{Another social twist}

As we have noted, the strategy adopted by the old philosophers is often to turn the arguments of the new philosophers back on themselves. This concerns in particular the use of language: as we have seen, the old philosophers criticize the new philosophers for being all words when they state that some corpuscles endowed with certain motions are the causes of certain phenomena. Another example would be the way they accuse Descartes of playing with words

\footnotetext{
${ }^{108}$ Ibid., $\S 82-83$, pp. 159-161.

${ }^{109}$ Ibid., § 103, p. 195: “[C]es pensées qui emportent cette réflexion qu’elles font indivisiblement sur ellesmêmes, sont le seul caractére de la spirituialité...."

110 Ibid., § 105, pp. 198 f.

${ }^{111}$ Ibid., § 107, p. 202.

112 Ibid., § 108, p. 205.
} 
when, introducing a distinction between "indefinite" and "infinite," he qualifies the world as "indefinite," and not "infinite." 113 But the explanation that the ancient philosophers give of this relation to language is not the desire to appear more knowledgeable than common people.

According to the old philosophers, the problem with the modern philosophers is rather that they are superficially only interested in public approval. Again and again, their ignorance of old philosophy is outlined and it is generally noted that they did not bother to acquire the skills necessary for the practice of philosophy. ${ }^{114}$ According to the old philosophers, they do not seek to establish anything serious, but only to call attention to themselves in the salons by making fun of their opponents, even by insulting them. Rochon is here most telling:

Your gentlemen speak easily; when in the midst of a circle, they say whatever they please regarding the doctrine of Aristotle, with no one there to contradict them. They then ridicule everything... One mustn't be astonished if so many people who have never read Aristotle and who have never heard of the ordinary philosophy, except in the manner it pleases these gentlemen to speak of it, think that Aristotle's philosophy is as they describe it. This manner is assuredly not very honest. ${ }^{115}$

\footnotetext{
113 Babin, Journal, p. 42; Rochon, Lettre d'un philosophe à un cartésien de ses amis, § 14, pp. 27-29; Huet, Censura philosophiae cartesianae, chap. 5, § 5, pp. 149-150. For a contextualisation of this distinction, see Ariew, Descartes and the Last Scholastics, chap. 8, pp. 155-171.
}

114 See for example La Grange, Les principes contre les nouveaux philosophes, Preface, $\S 33$, chap. 34, § 1 , chap. 39, $\S 3$, chap. 45, § 9, chap. 50, § 1, resp. pp. 30, 450, 503, 569 and 599. Huet, Censura philosophiae cartesianae, chap. $8, \S 7$, pp. 196-202, insists that Cartesians profess to despise erudition in general, and Latin in particular, see p. 201: "Quinetiam adeo inconsiderate imperitos se rudes produnt, ut vix alterius quam alterius quam vulgaris linguae usum concedant in scribendo, nec aliam probent Latinatem, quam simplicem, incomtam, $\&$ facilem; ne sibi scilicet, cum legent, saepius recurrendum sit ad interpretem. Jam ergo ludibrium debemus Cartesianis, quod eruditi sumus." Even if he presents philosophy as written for honnêtes gens (see supra the references given note 39), Rapin, La comparaison, Avertissement, pp. 275-277, insists that it implies erudition and arduous work.

115 Rochon, Lettre d'un philosophe à un cartésien de ses amis, § 51, pp. 129 f. See as well ibid., § 58, p. 140: “[C]es Messieurs prennent tant de plaisir à ne parler jamais qu'en riant de la Philosophie vulgaire: qu'ils en prennent les lambeaux qu'ils jugent estre les plus propres pour donner à leurs auditeurs l'idée qu'ils pretendent de cette Doctrine"; La Grange, Les principes contre les nouveaux philosophes, Preface, § 44, p. 40: "Pour ce qui est de Gassendi \& de Descartes,... n'ayant pû, ou n'ayant point osé combattre par raisons nostre Philosophie, ils se sont contentez de luy insulter"; Pardies, Discours de la connaissance des bêtes, § 6, p. 9: “[T]out ceci... semble d'abord plus tenir de la galanterie d'un faiseur de Romans, que de la pensée serieuse d'un 
Later on, Rochon notices, not without wit, a kind of pragmatic contradiction between the public of the salons that the new philosophers cultivate and the mechanical knowledge that they claim. This contradiction would be fully revealed if the new philosophers actually possessed the knowledge in question: of course the audience does not want to know what corpuscles actually produce this phenomenon, because such knowledge would be better suited to a locksmith or a watchmaker. ${ }^{116}$

Concerning the principle of authority, we can distinguish two types of strategies in the counterattack of the old philosophers. On one hand, they admit that one must follow the truth rather than Aristotle. Highlighting the historical and doctrinal distance that separates Aristotle from his later commentators, some of them call for a return to the true meaning of Aristotle, that is to say, the truth and nothing but the truth. In particular this is the case with Fabri, who intends to end the scholastic digression and to restore the thought of Aristotle to its literal and authentic meaning, and eliminate the corruptions imposed upon it by the Arabs and, to a lesser extent, the Spanish. ${ }^{117}$ This analysis was made popular by Rapin in his Comparaison

Philosophe"; Huet, Censura philosophiae cartesianae, chap. 8, § 3, p. 185: "Ac tam absurdis commentis ut fidem quaerant factionis hujus participes, adversarias sibi sententias Praejudiciorum... infamare solent; tum praesertim cum rationibus carent ipsi argumentis."

116 “Car enfin, Monsieur, à vous entendre parler on diroit que d'une école de Philosophie vous voudriez faire une boutique de Serrurrier ... Un honnête homme se doit-il mettre en peine de toutes ces petites particularitez ... Quoy voudriez-vous que les Dames se fissent écolieres des Horlogers pour apprendre le nombre \& l'engrainement des dents de chaque roüe, \& de chaque pignon de leurs montres? faut-il donc qu'elles sçachent le biais dont sont inclinées les pallettes du balancier, ou la proportion qu'il faut donner à la diminution de la fusée ? n'est-ce pas assez qu'on sçache en general que tous ces mouvemens sont faits par la disposition par l'engagement des rouës \& des ressorts, ce que vous appelerez, si vous voulez, vertu indicative ou sonorifique?" (Rochon, Lettre d'un philosophe à un cartésien de ses amis, § 78, pp. 182-184). See as well "que dorenavant ils [Cartists] ne s'appliquent pas tant à l'étude de l'Anatomie ..., c'est la Science des Medecins et des Chirurgiens, qu'il ne faut point leur envier. Je leur conseil encor... de ne pas mettre tant de temps à faire des Experiences" (La Grange, Les principes contre les nouveaux philosophes, chap. 50, § 10, p. 611). This criticism contradicts what we explained on the relevance of experiences; notwithstanding the fact that the attitude of all the old philosophers towards the new sciences is not identical, their criticisms are sometimes more eristic than constructive.

${ }^{117}$ Fabri, Physica, Auctor lectori, §§ 7-9, n.p.; id., Epistolae tres de sua hypothesi philosophica, I §§ 26-27 and II $\S 4$, resp. pp. 57-58 and 70; id., Euvres de Fabri, vol. IV, f. 210r. These texts are quoted and commented in Roux, "La philosophie naturelle d'Honoré Fabri," pp. $91 \mathrm{f}$. 
d'Aristote et de Platon, and, much more radically, in his Réflexions sur la philosophie, that are both referred to by new philosophers. ${ }^{118}$

On the other hand, they denounce the manner in which Descartes became an authority for the new philosophers just as Aristotle was an authority for the old philosophers. Although the term "sect" is not necessarily pejorative, as it is still commonly used for a school of philosophy, it certainly is pejorative when La Grange compares Cartesians to sects of heretics, which, having fallen in love with some extravagant opinion, then support it against all odds. ${ }^{119}$ Descartes is called the master and doctor of the Cartesian philosophers and Régis their prince. ${ }^{120}$ Therefore, to follow Rapin, what one believed to have won by freeing oneself from the philosophy of Aristotle is at once lost by submitting to the yoke of Descartes:

[A]ll these fine precepts, which are given to remove us from the preoccupations of education, custom, authority, and to heal us of all popular preconceptions, are only traps for our credulity. One speaks of liberty only to impose a new yoke. This is only giving to the Moderns what one wants to take away from the Ancients, and one wants to destroy the credit of Aristotle only to establish that of Descartes. ${ }^{121}$

118 “Les Arabes s'étant rendus les Maîtres du monde, par leurs conquêtes, dans les siecles suivants, firent une espece de revolution dans les lettres, aussi bien que dans l'Empire. Le caractere de leur esprit, subtil, rêveur \& profond, qui les attacha trop litteralement au texte d'Aristote, leur fit prendre une maniere de raisonner abstraite, qui s'écarta un peu de la solidité des Grecs \& des Latins.... Outre que la Philosophie devint pointilleuse sous les Arabes, par ces precisions \& par ces concepts abstraits, qu'elle introduisit dans l'école, elle devint aussi tout à fait sauvage dans ses expressions” (Rapin, Réflexions sur la philosophie, § 15, pp. 358-359). Ibid., § 16, pp. 359-362 says that the Spanish scholastic period was full of disputes and extravagances. On the Arabic period, see as well id., La comparaison, IV, chap. 6, pp. $407 \mathrm{f}$., and, on the necessity of returning to a more literal understanding of Aristotle, pp. 415-417.

119 “Je ne m'étonne plus de lire dans l'Histoire Ecclesiastique, qu'il y a eu autrefois des Sectes d'Heretiques, qui ont enseigné des Opinions qui meritent plus le nom de folies \& d'extravagances, que celuy d'Erreur et d'Heresie. Quand les gens sont d'humeur à faire cabale, \& qu'ils s'attachent à quelqu'un qui dogmatise, ils ne manquent pas d'entrer dans ses sentimens, quelques absurdes qu'ils puissent estre" (La Grange, Les principes contre les nouveaux philosophes, chap. $24, \S 5$, pp. $344 \mathrm{f}$.). The association of "sect" with heresy is to be found as well in Daniel, Voyage du monde de Descartes, p. 131, but one finds by him also neutral uses of "sect," see for example ibid., p. 5.

${ }^{120}$ La Grange, Les principes contre les nouveaux philosophes, chap. 24, § 7, p. 349; Huet, Nouveaux mémoires pour servir à l'histoire du cartésianisme, p. 49.

${ }^{121}$ Rapin, Réflexions sur la philosophie, § 20, p. 369. 


\section{CONCLUSIONS}

Both, from a scientific and philosophical point of view, the texts under examination are rather poor in quality. I noted in the introduction that scientific practice is definitely autonomous with respect to the philosophical concern for the ontological principles and the norms of natural philosophy. Even if the protagonists of this confrontation were sometimes good scientists, like Rohault and Pardies, their scientific work was not involved in this debate. Nor is this confrontation always philosophically convincing; some of these arguments, if not most of them, are rehashed and inspired more by eristic considerations than by the desire of conceptual elaboration. Moreover, as a rule I did not discuss in detail their philosophical relevance, but indulged in a somewhat artificial and schematic reconstruction of the configuration they made up. All that being said, I think that this reconstitution better allows us to understand the way in which modern and ancient philosophers opposed each other in this crucial period.

First and remarkably enough, the two sides agree on a certain number of points: both accept the methodological principle that one must not multiply beings without necessity, they oppose the use of empty words, they criticize the abuse of the principle of authority, they want to ensure respect for the established religion. On all these points, old philosophers respond in echo to new philosophers, and as I will explain shortly, they had thus already conceded a great deal, not only in rhetorical techniques, but also in philosophical principles.

This is not to say that these new philosophers and these old philosophers agree on everything. Our systematic confrontation allows us to isolate the key issue of their opposition, the question of whether or not one needs substantial forms when doing natural philosophy. This question appears in three of the arguments I have isolated:

(1) For the new philosophers substantial forms lead to the unnecessary multiplication of beings since they are not necessary for causal explanations of phenomena. For the old philosophers, they are a metaphysical supplement, the function of which is not to explain physical phenomena, but to serve as their foundation.

(2) For the new philosophers, the elimination of substantial forms is tied to the bipartition of beings between body and soul. For the old philosophers, one needs substantial forms, and more generally entities that can be reduced neither to body nor to soul, to account for sensible qualities and for the sensitive knowledge of animals. (3) As for religion, which I deliberately left aside, the question is to know, if it is the elimination or the conservation of substantial forms that is the most respectful of 
religion. Both ancients and moderns affirm that the positions of their opponents on substantial souls can lead to certain difficulties with respect to the beliefs of established religion. For example, moderns say that substantial forms are material and perishable, and thus constitute a precedent that can lead libertines to wonder if our human souls are in fact immaterial and immortal. ${ }^{122}$ But, turning their arguments against the new philosophers in a procedure that we have often encountered in this paper, ancients say that refusing substantial forms to animals will sooner or later lead most of us to think that there is no reason to make an exception for men. ${ }^{123}$ Pardies notes that, given the symmetry between the two arguments, such a reductio ad libertinum does not constitute a way to conclude in either direction:

Some think that this opinion that denies souls for animal is dangerous and that it favors the impiety of the libertines...: For, they say, once one admits that all the operations of animals can be carried out without a soul and by the sole machine of the body, we will soon take the next step and say that all operations of men can also be done by a similar disposition of the machine of their body.... They don't perhaps reflect that one can oppose a similar reasoning and say that once you admit that everything admirable that happens with animals can happen by means of a material soul, would you not soon take the next step and say that everything that happens in men can also be done by means of a material soul? Up to then everything is equal: one has no more right than the other to reproach their feelings and to make them odious on the grounds of the consequences that could be drawn in favor of the impious. $^{124}$

To tell the truth, one gets the impression that this is rather used as a deterrent for one's opponent than an opportunity to explore in greater depth the general concepts concerning the world and what we can know of it. Considering the symmetries existing between arguments in general, one wonders if this controversy had any winner. And in a sense, we knew the answer to this question right from the beginning. As a rule, newcomers are by definition the

\footnotetext{
122 Arnauld and Nicole, La logique, III, chap. 19, § 2, p. 245; Rohault, Entretiens sur la philosophie, p. 145; Clerselier, Preface, in Rohault, CEuvres posthumes, n.p.

${ }^{123}$ Daniel, Suite du voyage du monde de Descartes, p. 71.

${ }^{124}$ Pardies, Discours de la connaissance des bêtes, § 49, pp. 99 f.
} 
winners, and this is no exception: it has already been established that between 1670 and 1690 most teachers, beginning with Parisian seculars, gave up substantial forms and replaced them with mechanical explanations. ${ }^{125}$ But a systematic study such as mine allows to reach more nuanced conclusions.

I wanted to give the old philosophers a chance to speak for themselves, and to avoid writing a triumphalist history where the new follows the old as day follows night. Their actual competences in physics are quite diverse, the two extremes being Pardies and La Grange: the first one was a brilliant scientist, who offered a pertinent criticism of Newtonian optics, the second one seems to be totally uninformed about seventeenth-century physics, and goes from one bit of nonsense to the next when dealing with the relativity of motion. ${ }^{126}$ However, because of their long acquaintance with the scholarly practice of erudite commentary, all of the old philosophers I dealt with here developed an advanced knowledge of the works of the new philosophers, referred to precise passages and were able to discuss different theses. Thus the general impression is that unlike the obscure physicians muttering away in bastardized Latin in The Imaginary Invalid, they managed to reply to the new philosophers. Some of them even knew how to get the mockers from high society on their side, adapting the tone of the honnêtes gens and manipulating with ease the polemical tools of satire and parody. But to have recourse to such techniques is in fact already to concede a good deal.

This can be easily shown by wondering what exactly the old philosophers meant to defend in the scholastic entities, and in particular with regards to substantial forms. ${ }^{127}$ In the Aristotelian tradition saying that a natural being has a substantial form is a first approximation to answering three questions: why is this being $a$ substance rather than a collection of properties? Why is it a substance, so that some of its properties reestablish themselves after undergoing a change? Why is it a substance of this species rather than of another? The issue is not only to affirm the existence of entities known as "substantial forms," but to cover reality with a complex network of distinctions, for example between

\footnotetext{
${ }^{125}$ See Brockliss, French Higher Education, pp. 357-360; for more detailed case studies on the vanishing of Aristotelian principles in the context of teaching, see id., "Aristotle, Descartes and the New Science"; id., "Descartes, Gassendi, and the Reception of the Mechanical Philosophy"; id., "Pierre Gautruche et l'enseignement de la philosophie de la nature."

${ }^{126}$ La Grange, Les principes contre les nouveaux philosophes, chap. 9, §§ 2-6, pp. 136-144.

127 On the emergence of the notion of substantial form, see Copenhaver, "Scholastic Philosophy and Renaissance Magic"; on its complexities in late scholasticism, see Des Chene, Physiologia, chap. 3, pp. 53-81.
} 
natural and artificial forms, or between substantial and accidental forms. Once these distinctions were made, one could take on the discussion of serious questions: how to explain the transformation from one form to another or from privation to form? Can forms exist separated from matter? And matter separated from any form? What distinguishes a being from one species from another being of the same species? Are there substantial forms associated with all the parts of an organic being? If so, what is their relation to the substantial form of this organic being?

But in the texts we have been examining, our ancients do not make these distinctions and enter only rarely into this type of discussion. ${ }^{128}$ To make themselves understandable to the new public of honnêtes gens, they do not burden themselves with these details, and sometimes seem to content themselves with the affirmation that substantial forms exist. And in so doing, they concede a lot, for the new philosophers' criticism of the old philosophy did not simply concern the existence of substantial forms, but also that of a multitude of lesser beings, of complex distinctions, and the endless discussions that accompanied them. In other words, the old philosophers came to defend substantial forms in a spirit that was no longer scholastic. But substantial forms without scholasticism were nothing, or at least not much. They were no longer philosophical tools, but hollow and empty shells, symbols of the social positions that the old philosophers wanted to defend, inasmuch as they were teachers in the schools and universities, preceptors and spiritual directors. As is often the case, only when a belief is utterly dead it becomes important to defend it.

However, one last swing of the pendulum is necessary. Namely, it is striking to note that the criticisms the old philosophers addressed against Cartesianism are precisely the same who will be found again during Enlightenment: to neglect experience, to try to get away with using general words, to neglect phenomena that do not square with a predefined categorization of beings. In this sense, one can say that the ancient philosophers did not really lose their war, at least not completely: they participated in discussions of their time that determined the subsequent criticisms of Cartesianism. No doubt there is also a lesson in here, one general enough for us to conclude with. When the history of philosophy is not confined to a given work or to the works of a given author, it is often written like a play: stars lead, followed by a second-rate supporting cast, heroically taking turns on center stage, one coming to dethrone the preceding ones. Without doubt we will have to learn to write the

\footnotetext{
${ }^{128}$ Rather surprisingly, the most detailed discussion on the different scholastic options concerning substantial forms is to be found in Rohault, Entretiens sur la philosophie, pp. 112-117.'
} 
history of this multitude of so-called extras: without always being aware of that they may happen to define the plot. 